TQM

33,7

\section{2}

Received 12 November 2020 Revised 1 March 2021 25 June 2021

Accepted 1 July 2021

\title{
Exploring Corporate Social Responsibility in the Italian wine sector through websites
}

\author{
Benedetta Esposito, Maria Rosaria Sessa, Daniela Sica and \\ Ornella Malandrino \\ Department of Management and Innovation Systems, University of Salerno, \\ Fisciano, Italy
}

\begin{abstract}
Purpose - This paper aims to explore how the Italian wine industry discloses corporate social responsibility (CSR) practices and quality certifications and the corresponding determinants via websites. The study also aims to investigate the relationship between CSR practices and financial performance. The information consistency between the quality certificates reported on corporate websites and official database statements is also explored. Lastly, the paper investigates how the relationship between the size of wineries and CSR disclosure changes according to firms' geographic location.

Design/methodology/approach - This paper analyses CSR corporate communication via the websites of a sample of Italian wineries by adjusting the theoretical framework developed by Amran (2012) to the wine sector's peculiarities. Moreover, a cross-certification analysis and a moderation analysis were performed to fulfil the purpose of the research.

Findings - The analysis revealed the extensive use of CSR disclosure via websites. It was found that company size positively affects CSR disclosure and Quality Certification Disclosure (QCD), while geographic location slightly moderates the relationship between the two variables. In addition, a negative relationship between CSR disclosure and corporate financial performance and its reverse causality emerged. Moreover, for most wineries, information consistency between the quality certificates reported on corporate websites and official database statements was observed.

Research limitations/implications - The study's main limitation is that the search process was performed during lockdown. Therefore, the examined issues could change in the near future due to the shift in priorities that the COVID-19 pandemic is determining.

Practical implications - The results can help managers implement CSR disclosure and QCD practices to enhance stakeholder legitimacy and enable their companies to compete in strongly competitive international markets.
\end{abstract}

Originality/value - The paper represents the first study investigating online QCD and its consistency in the Italian wine sector.

Keywords Corporate social responsibility, Sustainability, Online disclosure, Wine sector

Paper type Research paper

\section{Introduction}

In recent decades, the need to orient production systems and consumption styles towards new innovative management models has increasingly been recognised. Furthermore, the ongoing crisis generated by the COVID-19 pandemic has further emphasised the need for both companies and consumers to adhere to the UN Sustainable Development Goals' guiding principles as part of the 2030 agenda (Siva et al., 2016). In this context, corporate social

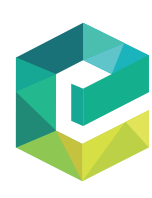

The TQM Journal Vol. 33 No. 7, 2021 pp. $222-252$ Emerald Publishing Limited $1754-2731$

DOI 10.1108/TQM-11-2020-0264
(C) Benedetta Esposito, Maria Rosaria Sessa, Daniela Sica and Ornella Malandrino. Published by Emerald Publishing Limited. This article is published under the Creative Commons Attribution (CC BY 4.0) licence. Anyone may reproduce, distribute, translate and create derivative works of this article (for both commercial and non-commercial purposes), subject to full attribution to the original publication and authors. The full terms of this licence may be seen at http://creativecommons.org/licences/by/4.0/ legalcode 
responsibility (CSR) and quality are considered pivotal elements for developing forwardlooking strategies capable of creating social value for all stakeholders. Moreover, policymakers, legislators, financial institutions and influence groups are encouraging companies to communicate sustainable performance (Kolk, 2004).

In this context, the wine industry is particularly committed to implementing socially responsible practices, which could be an excellent opportunity for the overall sector (Cobelli et al., 2021). Furthermore, growing attention is being paid to health, food quality and safety, traceability and environmental issues with regard to wine products (Arcese et al., 2017). Consequently, the need to fulfil stakeholders' expectations has prompted an increasing number of wine companies to integrate CSR practices into their business strategies (Henson and Reardan, 2005; Hollebeek et al., 2007).

Several scholars have emphasised the growing interest stakeholders are taking in environmental, social and governance (ESG) performance information (e.g. Atan et al., 2016; Fatemi et al., 2018; Albitar et al., 2020). In particular, some research has demonstrated that stakeholders have become much more involved in CSR issues that represent critical elements for organisations' competitiveness (Fait et al., 2019). Since stakeholders are involved in sustainable and ethical practices, wine companies are called upon to communicate their ESG performance. In this vein, Internet technology represents the optimum medium used by firms to communicate CSR corporate practices (Chaudhri and Wang, 2007). However, the information provided on websites is at the companies' discretion, and not all firms pay the same attention to communicating these issues.

So that, some scholars have started to explore CSR disclosure online (Rodriguez-Bolivar et al., 2013; Fait et al., 2019), conscious that websites could improve companies' relationships with their stakeholders (Cobelli and Wilkinson, 2020). In particular, Rodriguez-Bolivar et al. (2013) argued that this communication channel reaches stakeholders speedily and require lower costs, offering better transparency and accountability. Accordingly, a similar investigation could be extended to the wine sector, which remains less explored. Only a few contributions have investigated CSR disclosure in the wine sector (e.g. Fait et al., 2019; Iaia et al., 2019). In order to improve the extent of the research on CSR disclosure in this field, the present study investigates a new way of disclosing CSR practices and performance (i.e. wine corporate websites). In this context, the disclosure of CSR practices via websites is expected to positively influence the firm's performance and ethical reputation, representing an essential tool for gaining stakeholder legitimacy (Aggelogiannopoulos et al., 2007). However, the information reported on corporate websites is not controlled by authorities (Carvalho et al., 2018). Thus, a potential information gap concerning what is disclosed by companies online may emerge.

Considering the pivotal role of quality certifications in the agri-food sector and their contribution to guaranteeing wine products' quality and safety and enhancing their reputation and competitiveness (Notarnicola et al., 2003), this study explores CSR using a twofold dimension. Indeed, both a CSR disclosure and a quality certification disclosure (QCD) index were used as proxies to explore CSR in the Italian wine industry. Moreover, this sector is closely linked to the production's territory - better known as the "terroir" - and its behavioural habits (Ciasullo and Festa, 2014). Thus, the geographical location may emerge as a variable that could influence companies' CSR disclosure practices. Despite the increasing attention paid by academics to CSR in the wine sector, disclosure via websites is still vastly unexplored in the extant literature.

Starting from these assumptions and adopting a theoretical background based on the integration between legitimacy theory and institutional theory, this paper aims to detect how online disclosure may improve CSR as a competitiveness driver in the Italian wine sector. Therefore, this paper is divided into six sections: After the introduction, the second section presents an overview of the wine industry's CSR. Moreover, prior research on CSR disclosure and research objectives is provided. In the third section, the theoretical background is 
TQM

33,7

discussed. In addition, research hypotheses are developed. The fourth section describes the research methodology. In the fifth section, the results of the analysis are presented. Then, primary considerations are provided, highlighting the principal outcome of the study. Finally, the authors provide the main conclusions, limitations and managerial implications of the study.

\section{Literature review}

2.1 Sustainability and corporate social responsibility in the wine sector

Over the decades, the idea that firms should take responsibility towards stakeholders and society at large for the impacts of their activities has been accepted worldwide. Stakeholders' increasing pressure to engage in social and environmental responsibility has encouraged companies to implement sustainable practices and apply social responsibility principles to their strategies to obtain legitimacy for their operations. In this perspective, CSR has been widely intended as an instrument that "allows companies to express their commitment to sustainability” (Muñoz et al., 2021, p. 9).

Many definitions addressing CSR's multiple dimensions have been coined over time (Carrol and Shabana, 2010). One of the most influential CSR's scholars, Carroll, recognised that "the social responsibility of business encompasses the economic, legal, ethical, and philanthropic expectations that society has of organisations at a given point in time" (1979, p. 500). Later, in the Green Paper published in 2001 by the European Commission, the concept of CSR was associated with "the voluntary integration by enterprises of social and environmental issues in their commercial transactions and their relationships with their interlocutors" (European Commission, 2001). Such a definition reflects the triple-bottom-line approach proposed by Elkington (1998) and based on the Economic Social and Governance (ESG) responsibility paradigm, which turns out to be the file rouge among CSR's different approaches.

Literature has shown that CSR may be divided into internal and external dimensions (Inoue and Lee, 2011). The first explores human resources management, the improvement of the business climate, the management of workers' health and safety and the use of innovative technologies to reduce the environmental impact (Arcese et al., 2013). The second is mainly projected towards enhancing local communities' well-being, human rights defence and natural resource protection (Merli et al., 2015). Mainstream literature has demonstrated that implementing CSR strategies, both in terms of the internal and external dimensions, may be beneficial for companies (e.g. Pinkston and Carroll, 1996; Kotler and Lee, 2005; Lindgreen et al., 2009). Specifically, better social and environmental performance is conducive to better financial results, which, in turn, generates - in the medium-long term - virtuous circles in productivity, competitiveness and image (Porter and Kramer, 2007).

However, the internalisation of the CSR concept goes hand in hand with the need to communicate with external stakeholders the sustainable policies and practices implemented (Campbell, 2004; Merk1-Davies and Brennan, 2007; Nicolò et al., 2020a). CSR disclosure entails firms' communication about their activities' social and environmental impacts and the relationships established with stakeholders via institutional communication channels (Gray et al., 2001; Campbell, 2004). In this light, the disclosure of CSR practices - considered a voluntary information process that does not require accounting standards, rules and regulations (Said et al., 2009) - is likely to, on the one hand, improve firms' corporate reputation (Kang and Hustvedt, 2014) and, on the other hand, generate sustainable competitive advantages, which, in turn, lead to an increase in corporate financial performance (Du et al., 2010; Salehi et al., 2018). The increasing awareness of CSR issues is reflected in the growing number of companies that spend huge amounts of resources on disclosing information about their environmental and social performance (Gamerschlag et al., 2011). Companies develop CSR disclosure practices for manifold reasons. First, firms that 
communicate socially responsible information can positively influence their trade performance. Second, it allows companies to obtain legitimacy from a specific target group. Lastly, CSR disclosure is fundamental to respect the virtual social contract between firms and the local society they operate in (Mathews, 1995; Kolk, 2004).

In this context, CSR is progressively gaining importance in the wine sector too (Barber et al., 2006; Cobelli et al., 2021). The discussion about this relevant topic in the field of wine is closely linked to the sustainability concept. The International Organisation of Vine and Wine (OIV), in Resolution CST 1/2004, defined wine sustainability as a "global strategy on the scale of grape production and processing systems, also incorporating the economic sustainability of structures and territories, producing quality products, considering requirements of precision in sustainable viticulture, risks to the environment, product safety and consumer health and valuing of heritage, historical, cultural, ecological and landscape aspects" (2008, p. 2). Such a concept casts a spotlight on the close interconnection existing between CSR and sustainability. Later, this definition was empowered by Resolution CST 1/2008, which provided guidelines for environmental assessment at all stages of the wine supply chain. More recently, with Resolution CST 1/2016, environmental, social, economic and cultural aspects have been included in the General Principles of Sustainable Viticulture. In this light, various national and international frameworks were designed to bring sustainability principles into practice: general frameworks applied globally (such as ISO 14001, life cycle assessment and Global Reporting Initiative [GRI] reports) and national and regional frameworks, which are territorial-based (e.g. Sustainable Wine South Africa framework, Sustainable Winegrowing New Zealand, National Code of Sustainability for the Chilean Wine Industry, Terra Vitis, EQUALITAS and VIVA certifications) (Flores, 2018).

Consequently, the wine sector appears to be committed to CSR from a twofold perspective. On the one hand, CSR confronts threats from several issues, such as climate change, water and energy availability and chemical exposure (Flores, 2018). On the other hand, it enhances competitiveness among firms - improving quality and economic efficiency from an environmental perspective and boosting companies' reputations. Moreover, incorporating CSR pillars in wine production goes hand in hand with the need to disclose to stakeholders how companies create and co-create value for society, supporting territories to move towards sustainable development (Fait et al., 2019).

Thus, wine firms are called upon to communicate CSR practices and performances to their stakeholders in order to obtain legitimacy.

\subsection{Prior research on CSR disclosure online}

Several empirical studies investigating the extent and quality of CSR disclosure have been conducted in several countries such as: Malaysia (Haniffa and Cooke, 2005; Said et al., 2009; Rahman et al., 2011); Australia (Cuganesan et al., 2010); Germany (Gamerschlag et al., 2011); Portugal (Branco and Rodrigues, 2008; Siregar and Bachtiar, 2010); Spain (Reverte, 2009); Greece (Giannarakis, 2014); China (Patten et al., 2015); India (Kansal et al., 2014); France (Chauvey et al., 2015) and Italy (Mio et al., 2015; Tibilietti et al., 2020). Studies examining CSR disclosure practices across different geographical contexts also emerged (Gray and Milne, 2015; Yu et al., 2017; Russo-Spena et al., 2018).

These studies mainly focused on annual reports, which have traditionally been the most commonly used tool in disclosing social and environmental reporting (Adams et al., 1998; Line et al., 2002). However, these documents do not provide immediate access to information for all the stakeholders (Suárez-Rico et al., 2019). Considering the growing request for transparency and accountability, scholars have begun to investigate alternative reporting channels. Websites have emerged as a more useful tool for improving disclosure to stakeholders (Douglas et al., 2004; Lodhia et al., 2020; Manes-Rossi et al., 2018; Nicolò et al., 2020a, b).
Corporate Social Responsibility in wineries

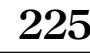


TQM

33,7

226

The literature on website-based corporate disclosure has demonstrated that these channels provide more flexibility, lower costs, timeliness and speed regarding CSR communication (Rodriguez-Bolivar et al., 2013). Moreover, Lodhia et al. (2020) have highlighted that social media has changed reporting dynamics, incorporating dialogue and engagement with stakeholders to seek legitimacy.

In keeping with these arguments, several scholars have investigated CSR disclosure through websites in different sectors (Table 1): universities (e.g. Garde Sanchez et al., 2013; Rodriguez Bolivar et al., 2013; Garde Sanchez et al., 2021); banks (e.g. Sobhani et al., 2012; Kiliç, 2016; Palazzo et al., 2020; Georgiadou and Nickerson, 2020); the hospitality industry (e.g. Hsieh, 2012; Iazzi et al., 2020) and agro-food (e.g. Iaia et al., 2019; Dos Santos et al., 2020).

However, despite the journey towards CSR disclosure having matured, the agro-food sector, and, in particular, the wine sector, remains virtually unaddressed. Thus, despite the latter's relevance, only a few contributions were detected. In particular, Fait et al. (2019) observed how the wine sector's sustainability disclosure could reduce information discrepancies among consumers. However, they analysed online virtual communities to investigate how online communities of practice should reduce CSR's informative asymmetries. Differently, Iaia et al. (2019) investigated the CSR communication models of Italian wine family businesses. As a result, they provided interesting insights into the impact of ownership structure on online CSR disclosure.

Information disclosure plays a pivotal role for all stakeholders. In particular, scholars have investigated the impact of CSR disclosure on consumer's decision-making process (Pradhan, 2018). Accordingly, websites should be considered a proper communication channel to reach consumers (Hollebeek et al., 2007; Yen, 2014; Cobelli et al., 2021). More specifically, online disclosure should support companies in enhancing consumers' involvement in corporate

\begin{tabular}{|c|c|c|c|c|c|}
\hline Authors & Year & Journal & Country & Sector & $\begin{array}{l}\text { Research } \\
\text { technique }\end{array}$ \\
\hline $\begin{array}{l}\text { Rodriguez } \\
\text { Bolivar et al. }\end{array}$ & 2013 & $\begin{array}{l}\text { Journal of Environmental Policy } \\
\text { and Planning }\end{array}$ & USA & University & Content analysis \\
\hline $\begin{array}{l}\text { Garde Sanchez } \\
\text { et al. }\end{array}$ & 2013 & $\begin{array}{l}\text { Environmental Education } \\
\text { Research }\end{array}$ & USA & University & Content analysis \\
\hline $\begin{array}{l}\text { Garde Sanchez } \\
\text { et al. }\end{array}$ & 2021 & $\begin{array}{l}\text { International Journal of } \\
\text { Environmental Research and } \\
\text { Public Health }\end{array}$ & USA & University & Content analysis \\
\hline Sobhani et al. & 2012 & Journal of Cleaner Production & Bangladesh & Banking & Content analysis \\
\hline Kiliç & 2016 & $\begin{array}{l}\text { International Journal of Bank } \\
\text { Marketing }\end{array}$ & Turkey & Banking & Content analysis \\
\hline Palazzo et al. & 2020 & $\begin{array}{l}\text { International Journal of Bank } \\
\text { Marketing }\end{array}$ & Worldwide & Banking & Content analysis \\
\hline $\begin{array}{l}\text { Georgiadou and } \\
\text { Nickerson }\end{array}$ & 2020 & $\begin{array}{l}\text { Corporate Communications: An } \\
\text { International Journal }\end{array}$ & UAE & Banking & Content analysis \\
\hline Hsieh & 2012 & $\begin{array}{l}\text { International Journal of } \\
\text { Contemporary Hospitality } \\
\text { Management }\end{array}$ & Worldwide & Hospitality & Content analysis \\
\hline Iazzi et al. & 2020 & $\begin{array}{l}\text { Corporate Social Responsibility } \\
\text { and Environmental } \\
\text { Management }\end{array}$ & Worldwide & Hospitality & Content analysis \\
\hline Dos Santos et al. & 2020 & Social Responsibility Journal & Brazil & Agro-food & Content analysis \\
\hline & 2019 & & Italy & & Survey \\
\hline Iaia et al. & 2019 & British Food Journal & Italy & Wine & $\begin{array}{l}\text { Content analysis } \\
\text { and text mining }\end{array}$ \\
\hline
\end{tabular}

Table 1.

Main contributions about CSR disclosure via websites in different sectors

2020

2019 
social responsibility practices, influencing consumers' purchasing behaviour (Barber et al., 2006). Therefore, as suggested by Cobelli and Wilkinson (2020, p. 387), "consumer can easily access information about wine through the web and wine producers have the opportunity to expand into markets that may be unreachable otherwise".

Nonetheless, research dealing with CSR disclosure practices via websites in the wine sector is still scant.

Aiming to fill this gap, the present study focused on the context of Italian wine companies to address the following research objectives:

(1) To analyse to what extent Italian wine firms provide CSR and QCD through their websites.

(2) To examine potential explanatory factors of both CSR and QCD. In particular, the paper investigates the potential role of geographical location as a moderator variable in the relationship between the firms' size and CSR and Quality Certification disclosure levels.

(3) To analyse the information consistency between the quality certifications conveyed on firms' corporate websites and the information reported in the official certification authorities' databases.

\section{Theoretical framework and hypotheses development}

To address the research objectives, the present paper was developed following an interdisciplinary approach that combines two interdependent theories, that is legitimacy theory and institutional theory. Accordingly, Gray et al. (1995) emphasised that these theories might be considered complementary rather than competing frameworks of reporting behaviour. In this light, several studies have employed a theoretical framework that combines legitimacy theory with institutional theory (e.g. Haji, and Anifowose, 2017; Nicolò et al., 2020a).

Suchman defined legitimacy as "a generalised perception or assumption that the actions of an entity are desirable, proper, or appropriate within some socially constructed system of norms, values, beliefs, and definitions" (1995, p. 574). Whether a disparity occurs between society and organisation's value systems, a legitimacy gap may emerge, which have to be managed (Dowling and Pfeffer, 1975).

Therefore, from this standpoint, firms' survival depends on their ability to operate in accordance with societal expectations (Gray et al., 1996). However, according to their approach toward stakeholders, the legitimacy level differs among organisations (Deegan, 2002). Companies that require social and political support need a higher level of legitimacy than others (Patten, 1991; Lodhia et al., 2020).

In this perspective, wine industries are particularly interested in seeking a greater legitimacy level from their stakeholders (Arora and Lodhia, 2017). In this vein, communication between a company and its "significant" actors represents the pillar of legitimacy management (Suchman, 1995). Literature suggests that CSRD may help companies solve organisational legitimacy achievement problems (Brown and Deegan, 1998; Neu et al., 1998). Accordingly, firms must disclose their quality and sustainability practices to relevant stakeholders to appear socially aware and fulfil the interested parties' expectations (Deegan, 2002).

However, the problem of CSR disclosure may remain unexpressed under legitimacy theory. Some scholars advocate that firms' legitimacy is likely to be influenced by the legal, social, economic, cultural and political contexts in which they operate (Ortas et al., 2015). In this light, the institutional theory emerges as a theoretical perspective capable of explaining how firms react to the modification of institutional and social pressures to endorse legitimacy (Amran and Haniffa, 2011). Indeed, the pressures coming from the external environment in terms of norms, rules, routines and beliefs may influence firms' behaviours and structures, 
TQM

33,7

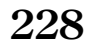

affecting, in turn, CSR disclosure practices (Nicolò et al., 2020a). More specifically, these pressures lead companies to adopt isomorphic behaviours - that is uniformity of practices to achieve and maintain legitimacy in the context in which they act (Kostova and Roth, 2002). Isomorphism - based on the uniformity of practices and policies according to institutional norms and values - can be mimetic, coercive and normative (Di Maggio and Powell, 2012; Wachira et al., 2019). Coercive isomorphism - stemmed from formal and informal pressures derives from regulatory bodies' external burdens. Formal pressures concern firms' compliance with regulations and directives. At the same time, informal pressures include guidelines, codes of conduct, and informal monitoring (Kim et al., 2016). Firms act in keeping with these pressures carrying out mandatory corporate practices to avoid hefty penalties (Wachira et al., 2019).

Consequently, normative and coercive pressures for CSRD promptly impact firms' disclosure activities according to each government's guidelines (Othman et al., 2011; Pedersen et al., 2013). For instance, global standards such as ISO reporting requirements could make companies answer these pressures to reach "legitimacy".

Mimetic isomorphism arises from the need to emulate the best practices of successful competitors that operate in the same industry sector (Di Maggio and Powell, 1991; Haji and Anifowose, 2017; Nicolò et al., 2020a). Consequently, firms that obtain legitimacy in their context may increase their survival opportunities by complying with such constraints to protect companies' reputations (Grecco et al., 2013). Lastly, normative isomorphism comes from external stakeholders (e.g. professional networks and industry bodies) that require system and process adaptation according to their values and social norms.

These three aspects of isomorphic behaviour may explain why organisations emulate recognised behaviours in their environment to gain legitimacy. Accordingly, companies operating in different industries with various institutional needs adopt different behaviours. In other words, some firms can be more ethically responsible than others due to the nature of their core businesses (Boutin-Dufresne and Savaria, 2004; Chen et al., 2015).

The wine sector appears to be primarily influenced by coercive and normative pressures; however, mimetic isomorphism also affects the sector. In this vein, Swinbank (2009) highlighted that institutions and regulators could be considered primum movens to increase wineries' interest in quality and sustainability by funding the implementation of particular practices and education programmes. Thus, the different institutional scenarios impact expectations concerning engagement in CSR. Symmetrically, firms operating in a common commitment context display the same level of attention towards these issues (MartinezFerrero et al., 2016).

Legitimacy and institutional theories have focused mainly on disclosure through static and periodic communication tools, such as annual and sustainability reports (Lodhia et al., 2020). Recently, websites and social media have replaced this static approach to disclosing interactive communication among stakeholders (Lodhia, 2018). Thus, organisations through the interactive power of websites - can easily seek legitimacy. Therefore, it is interesting to explore how companies use online reporting tools to obtain legitimacy from an institutional perspective.

Thereby, drawing on previous literature, it emerges that institutional theory and legitimacy theory are closely interconnected and that the integration of both provides a comprehensive framework on which the following research hypotheses should be built.

\subsection{Size}

Larger companies have more resources than smaller ones, making CSR engagement and quality disclosure easier (Gray et al., 1995; Nicolò et al., 2020b). 
Indeed, some scholars have shown that as the company's size increases, the number of stakeholders also grows (e.g. Cuganesan et al., 2010; Branco and Rodriguez, 2008; Gray et al., 2001). In addition, large companies have greater political and social pressures and are more influenced by external factors (Kiliç, 2016; Gamerschlag et al., 2011). Thus, the need to inform stakeholders has grown in order to obtain legitimacy both at the territorial and global levels. In this vein, Giacomini et al. (2020) and Boubaker et al. (2011) have demonstrated that as company size increases, the communication of sustainability practices and the need for accountability towards their stakeholders' grows. Similarly, legitimacy theory suggests that larger companies disclose more CSR information than smaller ones (Branco and Rodrigues, 2006; Kiliç, 2016).

Therefore, the following hypothesis is developed:

H1. There is a positive relationship between firm size and corporate social responsibility.

Several scholars have emphasised the advantages of voluntary certification schemes, highlighting benefits for producers and consumers (Anderson et al., 1999; Gomez Conde et al., 2012). In particular, Aggelogiannopoulos et al. (2007) showed that the implementation of quality management systems enhanced opportunities to access global markets, increased customer satisfaction, improved wine quality, reduced waste and enhanced productivity.

However, implementing a voluntary standard can be prohibitively expensive for small wineries that must incur high and unsustainable costs (Goedhuys and Sleuwaegen, 2013). To overcome this limitation, some scholars have demonstrated that the implementation of voluntary standards should be sustainable if small firms work cooperatively (Boselie et al., 2003; Handschuch et al., 2013). In this perspective, the size and the availability of resources (i.e. time, networks, human and financial capital) affect companies' approaches towards the implementation of sustainable practices and the adoption of voluntary certification standards.

Based on this assumption, the relationship between the company size and the implementation of quality certification standards should also be extended to QCD.

Given this argumentation, the following hypothesis is formulated:

H2. There is a positive relationship between the size of the company and its quality certification disclosure.

\subsection{Profitability}

Empirical studies dealing with the relationship between profitability and CSR disclosure have shown mixed findings. Some scholars have demonstrated - using different theoretical approaches - a positive relationship between profitability and CSR disclosure. In this line, Hackston and Milne (1996) have defined profitability as the factor that allows firms the flexibility and the freedom to communicate to stakeholders with more extensive social and environmental practices and performance. Similarly, other scholars have highlighted the positive relationship between profitability and CSR disclosure (e.g. Roberts, 1992; Haniffa and Cooke, 2005; Khan, 2010). Moreover, Ullmann (1985) and Roberts (1992) stated that a company with fewer economic resources will presumably invest in activities that directly impact its earnings, avoiding costs linked to social and environmental disclosure.

Nevertheless, other research has shown a negative (e.g. Preston and O'bannon, 1997; Muñoz et al., 2021) or insignificant (e.g. Patten, 1991; Siregar and Bachtiar, 2010) relationship between profitability and CSR disclosure. In particular, Muñoz et al. (2021) explored the relationship between CSR and performance in the Spanish wine sector. Their results showed that more environmentally and socially responsible wineries do not have a significant CSRperformance relationship. At the same time, Siregar and Bachtiar (2010) demonstrated that CSR disclosure initiatives add costs without any direct benefits. Mindful of these premises, it 
TQM

33,7

230

emerges that empirical studies have not arrived at a consensus. Doubts about the relationship between profitability and social performance are partially due to the lack of consensus on financial performance measurement (Margolis and Walsh, 2001).

Moreover, Scholtens (2008) showed how most studies had treated corporate financial performance as a dependent variable, while only a few studies have used corporate social performance as an independent variable. Additionally, dealing with the causality between corporate financial performance and corporate social performance, they highlighted two opposing perspectives. The first one is based on the assumption that good financial performance could support investments that enhance social and environmental performance (e.g. Roberts, 1992; Branco and Rodriguez, 2008). According to the opposing current, good environmental and social performance positively impacts financial performance due to the efficient use of resources and stakeholder legitimacy. This relationship could also be extended to the disclosure of environmental and social performance, allowing companies to obtain stakeholder legitimacy.

Based on what has been said thus far, the following hypotheses are developed:

H3. There is a relationship between corporate financial performance and CSR disclosure.

H4. There is a relationship between CSR disclosure and corporate financial performance.

\subsection{The moderating role of geographical location}

Following the theoretical framework previously described, geographical location plays a pivotal role in the relationship between the wine companies' size and CSR disclosure. Literature provides mixed findings on this issue. Martinez-Ferrero et al. (2016) argued that companies operating in a common scenario show the same commitments to CSR. Moreover, Spence et al. (2011) highlighted the fact that the local environment influences firms' strategic behaviours relative to the push and pull factors that orient them towards a more or less sustainability-oriented approach. Accordingly, He et al. (2015) demonstrated that the adoption of voluntary standards varies across the institutional environment and the economic development context within which industries operate.

Conversely, Zamir and Saeed (2020) demonstrated that even if firms operate in the same country, they should adopt different CSR and sustainability behaviours. Their results highlighted that companies located in major cities are more likely to be socially responsible. Furthermore, this assumption is supported by the results of other empirical studies, which showed that locality plays a critical role in shaping firms' sustainability behaviours (Chintrakarn et al., 2017).

The Italian wine sector is characterised by a close connection with the territory of origin due to the large variety of Italian native vines. In this context, the concept of terroir, usually used to describe a vine variety's characteristics, incorporates both hard (i.e. landscape, subsoil and infrastructure) and soft (i.e. society, culture, identity and community) assets. Thus, the territory, combined with the referenced market, becomes relevant to wine companies when developing competitive disclosure strategies and incorporating quality, sustainability and CSR practices.

Grounded in this background, the following hypotheses are developed:

H5. Geographical location moderates the positive relationship between the company size and the CSR disclosure level.

H6. Geographical location moderates the positive relationship between the company size and the QCD level.

Table 2 summarises the research hypotheses previously described, while Figure 1 provides the conceptual framework developed. 


\section{Research methodology}

Following previous studies conducted using a web content analysis methodology (Amran, 2012; Sobhani et al., 2012; Carvalho et al., 2018), this paper has been structured through a fivestep process. Differing from traditional corporate website content analysis, this work also provides a cross-case analysis. Therefore, the research methodology has been adapted according to the specific nature of this study.

\subsection{Sample construction and data collection}

The study was conducted in the year 2020. It seeks to explore to what extent Italian wineries communicate to their stakeholders quality, sustainability and CSR responsibility practices implemented through their websites. In addition, concerning the certificates of conformity to national and international quality standards (e.g. ISO 9001, ISO 14001, VIVA, EQUALITAS), this work has investigated the possible information gap between such corporate websites and the official databases of accreditation and certification bodies. Moreover, a moderation analysis has been performed to investigate how the effect of company size on sustainability disclosure differs according to the geographic location of the Italian wineries. Therefore, this research is a cross-sectional study developed using secondary data collected from websites and official databases (i.e. Accredia, BRC, IFS, VIVA, EQUALITAS and ISPRA).

The sampling process began by consulting the "ReportAziende" and "AIDA Bureau van Dijk International" databases. The search was carried out using the ATECO "11.02.1" and "11.02.2" codes, which uniquely identify the following activities: "Table wines and quality wines produced in specified regions" and "Production of sparkling wine and other special wines".

H Research hypotheses

H1 There is a positive relationship between firm size and Corporate Social Responsibility

$\mathrm{H} 2$ There is a positive relationship between the size of the company and its quality certification disclosure

H3 There is a relationship between corporate financial performance and corporate social responsibility disclosure

H4 There is a relationship between corporate social responsibility disclosure and corporate financial performance

H5 Geographical location moderates the positive relationship between the company's size and Corporate Social Responsibility disclosure level

H6 Geographical location moderates the positive relationship between the company's size and quality certification disclosure level
Corporate

Social

Responsibility in wineries 
TQM

33,7

\section{2}

The first 200 companies, according to market capitalisation, were selected. From the first screening, the resulting sample was 197 companies. After removing 24 companies, the final sample consisted of 173 wine businesses. All the organisations with websites under construction or websites undergoing maintenance or organisations whose corporate websites were unavailable were excluded from the sample. In addition, wine companies belonging to business groups with a common website were included in the sample only if the site had a specific section available (Carvalho et al., 2018). The final sample was divided into three sub-categories according to each company's size to determine whether the communication about quality, sustainability and CSR practices among wine companies differs concerning the company size. Enterprises with a turnover of less than $€ 10$ million were classified as small enterprises, totalling 61 companies. Those with a turnover of less than $€ 50$ million were classified as medium enterprises, giving a total of 84 wineries. In contrast, enterprises with a turnover exceeding $€ 50$ million were grouped in the large enterprises' sub-category, totalling 28 wine industries. Not surprisingly, most of the sample consisted of small and medium-size enterprises (SMEs), which characterise the Italian entrepreneurial fabric. Table 3 describes the sample.

\subsection{Coding framework and coding process}

The analysis's focus is subdivided into the following three topics: quality, sustainability and CSR. These aspects are interconnected and consequential in the evolutionary quality framework. For this reason, from an overall and complete analysis perspective, it was decided to articulate the analytical categories to provide an integrated exploration of the topics covered by this research.

The analytical categories are derived from previous studies dealing with sustainability disclosure and were adapted to the research context (Carvalho et al., 2018). They consist of the following:

(1) Structure of the corporate website.

(2) Corporate policies.

(3) Manuals, codes and other corporate documents.

(4) Sustainability indicators.

(5) Certificates and corporate registrations.

(6) Corporate sustainable projects.

Then, in accordance with previous research (Sobhani et al., 2012; Carvalho et al., 2018), a coding framework was chosen to establish the list of items for the analysis. The coding list developed by Carvalho et al. (2018) was adopted. Nevertheless, to investigate the quality, sustainability and CSR issues in the Italian wine industry, the items were adapted,

\begin{tabular}{lccrr}
\hline Geographic location & Small* & Medium** & Big*** & Total \\
\hline North & 29 & 43 & 18 & 90 \\
Center & 15 & 16 & 6 & 37 \\
South & 17 & 25 & 4 & 46 \\
Total & 61 & 84 & 28 & \\
Note(s): *Small: turnover $<€ 10$ milion & & & \\
$* *$ Medium: turnover $<€ 50$ milion & & & \\
$* * *$ Big: turnover $>€ 50$ milion & & & & \\
\end{tabular}

Table 3.

Sample description 
integrating the framework used by Sobhani et al. (2012). This choice's ratio was identified to incorporate pre-existing studies on CSR disclosure with quality and certifications in the wine sector, not yet investigated by scientific literature through web content analysis techniques. Table 4 displays the relationship between the categories and sub-categories that support the content analysis developed. In addition to content items (i.e. information acquired on websites), following previous research (Boubaker et al., 2011; Manes-Rossi et al., 2018), accessibility items were also added to the analytical framework.

These items deal with the accessibility of websites and are grouped into three categories:
Corporate Social Responsibility in wineries

Categories
1. Structure of the corporate web site
2. Corporate policies
3. Manuals, codes and other corporate
documents

4. Sustainability indicators

5. Corporate sustainable projects

6. Certificates and corporate registrations

\section{SC items}

1. The homepage displays the theme "CSR"

2. The homepage displays the theme "Sustainability" or

"Environment"

3. The homepage displays the theme "Quality"

4. A section displays the theme "CSR"

5. A section displays the theme "Sustainability" or

"Environment"

6. A section displays the theme "Quality"

7. Quality policy

8. Environmental policy

9. Sustainability policy

10. Social responsibility policy

11. Quality manual

12. Sustainability manual

13. Social responsibility manual

14. Code of ethics and corporate conduct

15. Code of good practices

16. Indicators about CSR

17. Indicators about environmental issues

18. Investing in energy projects

19. Investing in renewable energy

20 . Initiative to reduce energy consumption

21. Investing in waste recycling

22 . Investing in sustainable viticulture practices

23. Initiatives for water supply

24. Initiatives to reduce greenhouse gas emission

25. Rural development projects

26. Social projects

27. ISO 9001: 2008

28. ISO $9001: 2015$

29. ISO 14001:2004

30. ISO 14001:2015

31. OHSAS 18001/ISO 45001:2018

32. SA 8000

33. ISO $22000 /$ FSSC 2200

34. ISO 26000

35. Bio

36. VIVA

37. EQUALITAS

38. BRC

39. IFS

40. EMAS III
Score

$0-1$

0-1

0-1

0-1

0-1

0-1

0-1

0-1

0-1

0-1

$0-1$

0-1

0-1

0-1

0-1

0-1

0-1

0-1

0-1

0-1

0-1

0-1

0-1

0-1

0-1

0-1

0-1

0-1

0-1

0-1

0-1

0-1

0-1

0-1

0-1

0-1

0-1

0-1

Source(s): ${ }^{1}$ Table adapted from Carvalho et al. (2018) and Sobhani et al. (2012)

Table 4. Items 
TQM

33,7

\section{4}

(1) Technology.

(2) Interactivity with users.

(3) Navigability.

Thus, a final list of 12 accessibility items, shown in Table 5 , was developed in order to provide additional information about the accessibility of data on websites.

The research methodology applied in the present study was based on the content analysis technique. It may be defined as "a research technique for the objective, systematic and quantitative description of the manifest content of communication" (Berelson, 1952, p. 18), which allows researchers to make "replicable and valid inferences from data according to their context" (Krippendorff, 1980, p. 21). Inspired by previous studies on sustainability disclosure (Amran, 2012; Carvalho et al., 2018), the present paper aims to adapt this research methodology, typically used in the reporting sector, to investigate the level of communication with external stakeholders of wineries regarding quality, sustainability and CSR practices. According to McMillan (2000), the content analysis technique's benefits could also be enlarged to include web content analysis. A reliable coding process was adopted to explore online disclosure, following Dumay and Cai (2014).

Moreover, the information collected was analysed by constructing a disclosure index, representing one of the most suitable techniques available in the literature (Coy et al., 1993). Two different approaches towards such a disclosure index are retrieved in the literature: unweighted and weighted. The present study adopted the un-weighted approach because all the information collected and analysed has the same importance. Additionally, the research is not focused on a specific group of stakeholders. Lastly, by following this approach, potential subjectivity problems were reduced (Manes Rossi et al., 2018).

Accordingly, to develop an empirically valid and reliable analysis, three disclosure indices were constructed: (1) a quality certification disclosure index (QCDI), (2) an online sustainability disclosure index (OSDI) and (3) a global online sustainability disclosure index (GOSDI). Many scholars have used corporate social disclosure as a proxy for CSR (e.g. Gray et al., 2001; Haniffa and Cooke, 2005). Other studies have adopted ESG disclosure as a proxy for corporate transparency, management quality and management's potential to grow the business profitably in the medium-long term (e.g. Eccles et al., 2001; Giannarakis, 2014; Lawal et al., 2017). In this light, we have used the CSR disclosure index as a proxy for CSR. In addition, considering the pivotal role of quality issues in wine sustainability, the QCD index has also been used to measure CSR disclosure.

\begin{tabular}{llc}
\hline & Accessibility items & Score \\
\hline 1. Technology & 1. Fast download of the main website $(<10 \mathrm{~s})$ & $0-1$ \\
& 2. Graphs and images & $0-1$ \\
& 3. Use of sound files & $0-1$ \\
2. Interactivity with users & 5. Use of video files & $0-1$ \\
& 5. Access and link to information on sustainable activities & $0-1$ \\
3. Navigability & 6. Access to social network (Facebook, Twitter, Instagram, etc.) & $0-1$ \\
& 7. Text size (possibility of changing text size) & $0-1$ \\
& 8. Web map/table of contents & $0-1$ \\
& 9. Internal search engine & $0-1$ \\
& 10. Website in English & $0-1$ \\
& 11. Website Multilanguage (other European and international languages) & $0-1$ \\
& 12. Content menu always visible & $0-1$
\end{tabular}

Table 5.

12. Content menu always visible

$0-1$

$0-1$

$0-1$

$0-1$

$0-1$

$0-1$

$0-1$

$0-1$

$0-1$

Web accessibility items Source(s): ${ }^{1}$ Table adapted from Manes Rossi et al. (2018) 
As stated above, 40 items covering the three issues of quality and CSR were defined (Table 4). The procedure used to quantify the indices was based on an un-weighted dichotomous approach, under which an item scores " 1 " if the information is disclosed or " 0 " when no information is disclosed on the corporate website analysed (Haniffa and Cooke, 2005).

Thus, the following disclosure indices were calculated to conduct a comprehensive analysis and to answer the research questions (Amran, 2012).

(1) The QCD, calculated as follows:

where:

$\mathrm{QCD}_{J}=$ Quality Certification Disclosure Index

$l_{j}=$ Number of certification items; $l_{j}=14$

$X_{i j}=$ " 1 " if the wine company discloses the certification and " 0 " if it does not.

(2) The Corporate Social Responsibility Disclosure Index (CSRD), based on the content items (category 6):

$$
\mathrm{CSRD}_{J}=\frac{\sum_{i=1}^{n_{j}} X_{i j}}{n_{i j}}
$$

where:

$\mathrm{OSD}_{J}=$ Corporate Social Responsibility Disclosure Index.

$N_{J}=$ Number of content items; $n_{j}=26$.

$X_{I J}=$ " 1 " if the wine company discloses the items and " 0 " if it does not.

(3) Additionally, the Global Corporate Social Responsibility Index (GCSRD), considering both the content items from categories 1 to 5 (40) and the presentation items (12) and calculated using the following formula:

$$
\operatorname{GCSRD}_{J}=\frac{\sum_{i=1}^{l_{j}} X_{i j}}{l_{i j}}
$$

where:

$\mathrm{GCSRD}_{j}=$ Global Corporate Social Responsibility Disclosure Index.

$l_{j}=$ Number of total items (content and accessibility items); $l_{j}=52$.

$X_{i j}=$ " 1 " if the wine company discloses the items and " 0 " if it does not.

For all the indices, the synthetic value of the whole sample was calculated. In addition, the value of each sub-category of the sample (i.e. small enterprises, medium enterprises and large enterprises) was provided. This allows the study to assess whether the degree of online CSR disclosure varies according to the organisation's size.

The exploratory analysis of the sample websites was divided into two phases (i.e. the coding process and validation phase). The coding process was developed through a systematic content analysis of selected wine industry websites during June 2020 and performed by a single coder. In order to provide a more accurate and trustworthy examination (Cormier et al., 2009), the items were measured based on the analysis of the information disclosed on the web pages, while PDF attachments, Word files and other 
TQM

33,7

available documents were not examined (Striukova et al., 2008). The validation phase, rather, has the purpose of ensuring the consistency and reliability of the coding process. It was performed through a second examination of the selected websites in July 2020. If the outcomes were not identical, a third coding was carried out to monitor the stability of the adopted analytical process (Amran, 2012).

\subsection{Empirical model}

To test (H1), an equation in which the dependent variable representing the sustainability disclosure level on the corporate websites is explained by the size of the wine companies and the rest of the control variables was used. Thus, the following empirical model was tested:

$$
\left.\mathrm{CSRDI}=\gamma_{0}+\gamma_{1}(\text { Size })+\gamma_{2}(\mathrm{CFP})+\gamma_{3}(\text { Age })+\gamma_{4} \text { (Accessibility }\right)+\varepsilon_{i}
$$

where the CSRDI is the CSR disclosure index of Italian wine companies; $\gamma_{0}$ is the constant; $\gamma_{1}-$ $\gamma_{4}$ are the coefficients of the explanatory variables (size, CFP, age and accessibility) and $\varepsilon_{i}$ is the error. Return on assets (ROA) is used as a proxy for CFP.

To test the second hypothesis (H2), the following equation was tested:

$$
\mathrm{QCD}=\gamma_{0}+\gamma_{1}(\text { Size })+\gamma_{2}(\mathrm{CFP})+\gamma_{3}(\text { Age })+\gamma_{4}(\text { Accessibility })+\varepsilon_{i}
$$

In this case, the dependent variable is QCD.

In order to test the effect of the CSRDI on CFP and its reverse causality (H3 and H4), the following empirical models were developed:

$$
\begin{aligned}
& \left.\mathrm{CFP}=\gamma_{0}+\gamma_{1}(\mathrm{OSDI})+\gamma_{2}(\text { Size })+\gamma_{3}(\text { Age })+\gamma_{4} \text { (Accessibility }\right)+\varepsilon_{i} \\
& \mathrm{CSRDI}=\gamma_{0}+\gamma_{1}(\mathrm{CFP})+\gamma_{2}(\text { Size })+\gamma_{3}(\text { Age })+\gamma_{4}(\text { Accessibility })+\varepsilon_{i}
\end{aligned}
$$

Lastly, to determine the geographical location's moderating effect (H5 and H6), we used two equations in which the geographic location (GeoLoc) also explains the dependent variable. This relationship was tested following previous methodological studies on moderation analysis (Baron and Kenny, 1986; Normilia et al., 2017) through this dependence model:

$$
\begin{aligned}
\mathrm{CSRDI}= & \beta_{0}+\beta_{1}(\mathrm{Size})+\beta_{2}(\mathrm{GeoLoc})+\beta_{3}(\mathrm{Size} \times \mathrm{GeoLoc})+\beta_{4}(\mathrm{CFP})+\beta_{5}(\text { Age }) \\
& +\beta_{6}(\text { Accessibility })+\varepsilon_{i} \\
\mathrm{QCD}= & \beta_{0}+\beta_{1}(\text { Size })+\beta_{2}(\mathrm{GeoLoc})+\beta_{3}(\text { Size } \times \text { GeoLoc })+\beta_{4}(\mathrm{CFP})+\beta_{5}(\text { Age }) \\
& +\beta_{6}(\text { Accessibility })+\varepsilon_{i}
\end{aligned}
$$

The moderation variable, GeoLoc, and the interaction between the moderation variable and the independent variable, size, have been added.

\subsection{Cross-certification analysis}

Literature has shown that CSR disclosure could determine the risk associated with a lack of truthfulness (Debreceny et al., 2002) due to the difficulty of controlling information's use (Xiao et al., 2004). For this reason, to investigate information consistency concerning QCD, an additional analysis was carried out.

Research suggests that the adoption of quality standards, such as ISO, BRC and IFS certifications, provides both internal and external benefits for wine companies (Karipidis et al., 2009). More specifically, it enhances the ability to internationalise and increases customer satisfaction and company reputation. Additionally, the adoption of quality standards improves wine quality and, consequently, wine firms' competitiveness 
(Gomez Conde et al., 2012). Furthermore, other studies have emphasised that voluntary certification implementation can improve business performance, increasing labour productivity (Starke et al., 2012; Ullah et al., 2014).

This study's novelty is provided by cross-certification analysis, which allows the authors to investigate the information consistency concerning QCD.

This analysis was performed by consulting the following databases:

(1) ACCREDIA.

(2) BRC Directory.

(3) IFS.

(4) VIVA official list.

(5) EQUALITAS official list.

(6) ISPRA.

The research was performed by entering the VAT number or the company's name in the directory search bar. The coding criterion was based on a dichotomous approach, according to which a certification item scored " 1 " if the database reported a certification for the company or was equal to " 0 " if it was not registered. Subsequently, a cross-certification analysis was conducted (Table 6 ) by calculating the difference $(\Delta)$ between the information collected from the company's website and the information acquired from the official accreditation and certification databases. For each certification item, $\Delta$ scored " 0 " when there was asymmetric information and " 1 " in the case of consistent reporting between the two research sources.

\section{Results and discussion}

This section details the findings of the web content analysis and moderation analysis. In addition, the results of the cross-certification analysis are presented.

\subsection{Descriptive results}

Table 7 displays the descriptive statistics for the online disclosure indices of the wine companies in the sample. Concerning the QCDI, the mean value of 0.58 compared to the maximum of 1 indicates that the extent of online QCD among Italian wineries is still low.

\begin{tabular}{llr}
\hline & Certificates and corporate registration items & $\Delta$ score \\
\hline 1 & Certificate of conformity ISO 9001:2008 & $0-1$ \\
2 & Certificate of conformity ISO 9001:2015 & $0-1$ \\
3 & Certificate of conformity ISO 14001:2004 & $0-1$ \\
4 & Certificate of conformity ISO 14001:2015 & $0-1$ \\
5 & Certificate of conformity OHSAS 18001/ISO 50001 & $0-1$ \\
6 & Certificate of conformity SA 8000 & $0-1$ \\
7 & Certificate of conformity ISO 22000/FSSC 22000 & $0-1$ \\
8 & Certificate of conformity ISO 26000 & $0-1$ \\
9 & Certificate of conformity Bio & $0-1$ \\
10 & Certificate of conformity VIVA & $0-1$ \\
11 & Certificate of conformity EQUALITAS & $0-1$ \\
12 & Certificate of conformity BRC & $0-1$ \\
13 & Certificate of conformity IFS & $0-1$ \\
14 & Register of conformity EMAS III & $0-1$
\end{tabular}

Corporate Social Responsibility in wineries

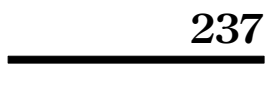


TQM

33,7

\section{8}

Regarding the OSDI and the GOSDI, similar results were obtained. However, the GOSDI gives a slightly higher average value.

Table 8 shows the descriptive statistics for the independent variables. Specifically, the variable "size" takes on a value from 15.43 to 19.32 and has a mean value of 16.96 and a standard deviation of 0.94 . The variable "geographic location" has a mean of 2.43 and a standard deviation of 0.83 . Regarding the control variables, the "ROA" reveals a mean value of 4.24 and a standard deviation of 4.49. "Age" provides an average value of 3.46 , while the "accessibility" variable has a mean value of 4.70 and a standard deviation of 1.57 .

\subsection{Results of the dependency model}

The results are presented in the following tables: Table 9 shows the models' results, based on which we test $\mathrm{H} 2$ and $\mathrm{H} 6$. Table 10 describes the model results, which test the relationship between $\mathrm{CFP}$ and corporate social performance and its reverse causality (H3 and $\mathrm{H} 4$ ). At the same time, Table 11 presents the models used to test $\mathrm{H} 1$ and $\mathrm{H} 5$.

The assumptions were tested for multicollinearity and heteroscedasticity (Boubaker et al., 2011). The variance inflation factor (VIF) was tested in all the models to assess possible

Table 7.

Descriptive analysis of the total companies

\begin{tabular}{lccc}
\hline Disclosure index & Minimum & Maximum & Mean \\
\hline QCDI & 0.00 & 0.58 & 0.102 \\
CSRDI & 0.00 & 0.468 & 0.106 \\
GCSRDI & 0.00 & 0.519 & 0.168 \\
\hline
\end{tabular}

Table 8.

Independent variables analysis

\begin{tabular}{lcccc}
\hline Independent variable & Min & Max & Mean & SD \\
\hline Size & 15.43 & 19.32 & 16.96 & 0.94 \\
GeoLoc & 1 & 3 & 2.43 & 0.83 \\
ROA & -4.76 & 21.11 & 4.24 & 4.49 \\
Age & 1.39 & 4.61 & 3.46 & 0.66 \\
Accessibility & 0 & 9 & 4.70 & 1.57 \\
\hline
\end{tabular}

Table 9.

Linear regression and moderation analysis results for QCD

\begin{tabular}{lcccrrr}
\hline & \multicolumn{3}{c}{ Model 1} & \multicolumn{3}{c}{ Model 2} \\
QCD & Effect & $t$ & $p$ & Effect & $t$ & $p$ \\
\hline Size & 0.330 & 4.082 & 0.000 & 0.0952 & 3.5527 & 0.0005 \\
GeoLoc $(1)^{*}$ & - & - & - & -0.0508 & -1.2559 & 0.2110 \\
GeoLoc $(2)^{* *}$ & - & - & - & -0.0153 & -0.5304 & 0.5966 \\
SizeGGeoLoc $(1)^{*}$ & - & - & - & -0.0759 & -1.7839 & 0.0764 \\
Size*GeoLoc $(2)^{* *}$ & - & - & - & -0.0553 & -1.7427 & 0.0834 \\
ROA & -0.011 & -0.150 & 0.881 & 0.0005 & 0.1679 & 0.8669 \\
Age & 0.027 & 0.359 & 0.720 & 0.0030 & 0.2143 & 0.8306 \\
Accessibility & 0.016 & 0.202 & 0.840 & 0.0021 & 0.2540 & 0.7998 \\
$R^{2}$ & 0.114 & - & - & 0.1478 & - & - \\
$F$ & 5.152 & - & 0.0001 & 2.0210 & - & 0.0789
\end{tabular}

Note(s): Dependent variable: Quality Certification Disclosure (QCD)

*GeoLoc (1) = The effect of the size on the QCD when the geographical location assumes value "2" that is in the centre of Italy

**GeoLoc (2) = The effect of the size on the QCD when the geographical location assumes value "3", that is in the north of Italy 
multicollinearity problems. The highest VIF was 3.567 for the variable "accessibility". These results eliminate multicollinearity problems. Moreover, the White test was performed to assess the heteroscedasticity of the results. All the models are statistically significant $(\phi<0.01)$; the regression models thus provide medium explanatory power (Model 1$R^{2}=0.114 ;$ Model 2- $R^{2}=0.0265 ;$ Model 3- $R^{2}=0.037$; Model $4-R^{2}=0.295 ;$ Model $5-R^{2}=0.295$; Model 6- $\left.R^{2}=0.1698\right)$.

The results of model 1 confirm the first hypothesis. A positive relationship between company size (as the explanatory variable) and online QCD (coef. $0.330, p=0.000$ ) emerges. From this, it can be determined that large enterprises offer stakeholders a great volume of information about the voluntary standards adopted. Our results confirm that, in accordance with previous literature, the implementation of voluntary certification standards requires a huge amount of resources. Thus, large companies are more likely to invest in certifications. In addition, large firms compete in international markets that consider quality certifications to be a conditio sine qua non for access to these markets in the wine sector. Concerning the relationship between company size and CSRD, model 5 provides similar findings (coef. 0.374, $p=0.000$ ). Model 5 suggests that larger companies disclose more CSR information than smaller ones. These results confirm previous evidence from several scholars (e.g. Branco and Rodrigues, 2006). Accordingly, they have highlighted that as company size increases, the need for accountability with regard to their stakeholders grows. Muñoz et al. (2021) have demonstrated how stakeholders are paying increasing attention to CSR issues in the wine

\begin{tabular}{|c|c|c|c|c|c|c|c|}
\hline Dependent variable & Effect & $\begin{array}{c}\text { Model } 3 \text { (CFP) } \\
t\end{array}$ & $p$ & Effect & $\underset{t}{\operatorname{lel} 4}$ (CSR & $p$ & \\
\hline CSRD & -0.25 & -0.266 & 0.591 & - & - & - & \\
\hline ROA & - & - & - & -0.018 & -0.266 & 0.591 & \\
\hline Age & -0.107 & -1.376 & 0.171 & 0.033 & 0.486 & 0.628 & \\
\hline Size & 0.107 & 1.181 & 0.239 & 0.374 & 5.177 & 0.000 & \\
\hline Accessibility & 0.104 & 1.182 & 0.239 & 0.276 & 3.830 & 0.000 & Table 10. \\
\hline$R^{2}$ & 0.037 & - & - & 0.295 & - & - & Linear regression \\
\hline$F$ & 1.535 & - & 0.194 & 2.706 & - & 0.000 & results \\
\hline
\end{tabular}

\begin{tabular}{|c|c|c|c|c|c|c|}
\hline \multirow[b]{2}{*}{ CSRD } & \multicolumn{3}{|c|}{ Model 5} & \multicolumn{3}{|c|}{ Model 6} \\
\hline & Effect & $t$ & $p$ & Effect & $t$ & $p$ \\
\hline Size & 0.374 & 5.177 & 0.000 & 0.0436 & 1.9967 & 0.0476 \\
\hline GeoLoc $(1)^{*}$ & - & - & - & 0.2703 & 0.3620 & 0.7178 \\
\hline GeoLoc (2) & - & - & - & -0.1232 & -0.3039 & 0.7616 \\
\hline${\text { Size*GeoLoc }(1)^{*}}^{*}$ & - & - & - & -0.0170 & -0.3701 & 0.7118 \\
\hline $\operatorname{Size}^{*}$ GeoLoc $(2)^{* *}$ & - & - & - & 0.0067 & 0.2719 & 0.7861 \\
\hline ROA & -0.018 & -0.266 & 0.791 & 0.0000 & 0.0109 & 0.9913 \\
\hline Age & 0.033 & 0.486 & 0.628 & 0.0063 & 0.5936 & 0.5536 \\
\hline Accessibility & 0.276 & 3.830 & 0.000 & 0.0196 & 3.6689 & 0.0003 \\
\hline$R^{2}$ & 0.295 & - & - & 0.1698 & - & - \\
\hline$F$ & 4.789 & - & 0.000 & 2.1357 & - & \\
\hline
\end{tabular}

Note(s): Dependent variable: Corporate Social Responsibility Disclosure (CSRD)

*GeoLoc (1) = The effect of the size on the CSRD when the geographical location assumes value " 2 " that is in the centre of Italy

**GeoLoc (2) = The effect of the size on the CSRD when the geographical location assumes value "3", that is in the north of Italy

Corporate Social

Responsibility in wineries

239

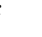
列 政 . . . 
TQM

33,7

\section{0}

sector. Thus, firms communicate their practices and performances concerning CSR and their quality certifications through their corporate websites to obtain legitimacy from their stakeholders.

Furthermore, enhancing stakeholder legitimacy allows wine firms to access new markets and internationalise. This finding provided by Aggelogiannopoulos et al. (2007) for Greek wineries may also be extended to Italian wine firms. Moreover, from the content analysis results, it also emerges that not all big companies communicate the certification standards implemented through their corporate websites, despite this information being available on the official databases of the certification and accreditation bodies. Some firms have provided evidence that they want to incorporate quality into their brands and try to obtain legitimacy from stakeholders through marketing campaigns. Consequently, internal efficiency improvements may be considered the main drivers for adopting quality or environmental management systems (Gomez Conde et al., 2012). Differently, CSR practices and performance are disclosed more by large companies.

Contrary to our expectation, Table 12 shows a negative relationship between CSRD and $\mathrm{CFP}$ and its reverse causality (Model 3 coeff. $-0.25 ; p=0.591$; Model 4 coeff. -0.018 ; $p=0.591$ ). These results are in line with research by Muñoz et al. (2021), according to which, in the Spanish wine sector, socially and ethically responsible wine firms do not have a positive impact on financial performance. Adopting CSR policies requires costs that do not promptly benefit financial performance and the managers' main purpose, i.e. improving firms' profits (McWilliams and Siegel, 2000; Friedman, 2007; Siregar and Bachtiar, 2010). Accordingly, our results show that even if CSR disclosure improves stakeholder legitimacy (Khan, 2010), this is not directly reflected in Italian wineries' financial performance.

The results of model 2 suggest that the second hypothesis is rejected. In fact, the effect of geographical location on the relationship between the size and the QCD is negative and significative (QCD: GeoLoc [center] = coef. $-0.0170, p=0.7118$; GeoLoc [north] $=$ coef. $-0.0153, p=0.0834$ ). Similarly, model 6 suggests that $\mathrm{H} 6$ do not appear very convincing. More specifically, the effect of geographical location on the relationship between the size and the CSRD is not significative (CSRD: GeoLoc [center] = coef. $-0.0508, p=0.2110$; GeoLoc [north] $=$ coef. $0.0067, p=0.7861)$.

To carry out a deeper analysis, the effects have been broken down in to simple slope, as shown in Table 12 . This additional analysis provides contradictory findings with respect to the direct effects of the interaction between the moderation variable and the size on QCD and CSRD (provided in model 2 and model 6). Results highlight that the conditional effect of the wineries' size on the QCDI in North and South Italy is positive and significant (i.e. North Italy coef. 0.0952, $p=0.0005$; South Italy coef. $0.0400, p=0.0340$ ). Differently, concerning the centre of Italy, the relationship is positive but not significant (coef. $0.0194, p=0.5476$ ). Similar results are retrieved for the conditional effect of the focal predictor on CSRD. A positive and

Table 12

Conditional effects of the focal predictors at values of the moderator

\begin{tabular}{|c|c|c|c|c|}
\hline \multirow[b]{2}{*}{ Geographical location } & \multicolumn{2}{|c|}{ QCD } & \multicolumn{2}{|c|}{ CSRD } \\
\hline & Effect & $p$ & Effect & $p$ \\
\hline GeoLoc $(1)^{*}$ & 0.0952 & 0.0005 & 0.0436 & 0.0476 \\
\hline GeoLoc $(2)^{* * *}$ & 0.0194 & 0.5476 & 0.0266 & 0.5036 \\
\hline GeoLoc $(3)^{* * * *}$ & 0.0400 & 0.0340 & 0.0504 & 0.0000 \\
\hline \multicolumn{5}{|c|}{$\begin{array}{l}\text { Note(s): *GeoLoc }(1)=\text { Conditional effect of size on dependent variable in South Italy } \\
\text { **GeoLoc (2) = Conditional effect of size on dependent variable in Middle Italy } \\
\text { ***GeoLoc (3) = Conditional effect of size on dependent variable in North Italy }\end{array}$} \\
\hline
\end{tabular}


significant relationship between company size and CSRD in the North (coef. 0.0504, $p=0.0000$ ) and South of Italy (coef. 0.0436, $p=0.0476$ ) has emerged.

Our findings highlight that even if the geographical location of the Italian wine sector represents an element that should impact firm behaviour, as suggested by Ciasullo and Festa (2014), both the relationships between the size of the company and CSR disclosure and QCD are not significantly moderated by this variable. Based on institutional theory, companies that operate in a common commitment scenario will adopt similar behaviours. In this vein, despite the connection between the territory and the value systems in the Italian wine sector impacting firms' behaviour, the institutions and regulators operate synergically, showing similar disclosure practices. This implies that Italian wine companies' stakeholders pay equal attention to CSR and quality issues, and, for this reason, firms have to fulfil similar information needs. Furthermore, the adoption of quality and sustainability certifications allows firms to compete in global markets. Thus, a homogeneous involvement of customers, consumers, suppliers, etc., in quality and CSR issues has emerged. In conclusion, our findings show that, in accordance with Martinez-Ferrero et al. (2016) and Spence et al. (2011), Italian wine firms operate in a common scenario and, accordingly, show the same commitments to quality and CSR. In this light, moreover, even if the local environment influences wine firms' disclosure behaviours, the Italian context provides similar external factors that orient them towards a more or less CSR-oriented approach.

\subsection{Cross-certification analysis results}

The cross-certification analysis results are displayed in Table 13. For each item, the frequency and the percentage of the information disclosed on the corporate websites and in the official databases are provided. The last column $(\Delta)$ displays, for each certification/ registration, the sum of the companies for which information consistency emerged. Among the items, ISO 9001:2015 and the Bio certifications report the highest scores. These results confirm Fait et al.'s (2019) findings, highlighting strong information discrepancies between the sustainable management systems implemented and what is disclosed on websites. Moreover, our findings suggest the need to orient wine industries towards enhancing QCD through their websites to improve stakeholder legitimacy. Furthermore, the crosscertification analysis has also highlighted that some companies disclose expired certifications and do not update the information provided on their corporate websites.

\begin{tabular}{|c|c|c|c|c|c|c|c|}
\hline \multirow[b]{2}{*}{ Certificate/Registration } & \multicolumn{2}{|c|}{ Website } & \multicolumn{2}{|c|}{ Databases } & \multicolumn{2}{|c|}{$\Delta$} & \\
\hline & Frequency & $\%$ & Frequency & $\%$ & Frequency & $\%$ & \\
\hline ISO $9001: 2008$ & 11 & 6.36 & 1 & 0.58 & 13 & 7.51 & \\
\hline ISO 9001:2015 & 23 & 13.29 & 47 & 27.16 & 41 & 23.70 & \\
\hline ISO 14001:2004 & 3 & 1.73 & 2 & 1.15 & 5 & 2.83 & \\
\hline ISO 14001:2015 & 12 & 6.93 & 15 & 8.67 & 7 & 4.04 & \\
\hline OHSAS 18001/ISO 45001 & 2 & 1.15 & 5 & 2.89 & 4 & 2.31 & \\
\hline SA 8000 & 2 & 1.15 & 0 & 0 & 2 & 1.15 & \\
\hline ISO 22000/FSSC 22000 & 16 & 9.25 & 15 & 8.67 & 19 & 10.98 & \\
\hline ISO 26000 & 0 & 0 & 0 & 0 & 0 & 0 & \\
\hline Bio & 41 & 29.70 & 74 & 42.77 & 69 & 39.88 & \\
\hline VIVA & 5 & 2.89 & 5 & 2.89 & 0 & 0 & \\
\hline EQUALITAS & 1 & 0.58 & 1 & 0.58 & 0 & 0 & Table 13. \\
\hline $\mathrm{BRC}$ & 42 & 24.27 & 42 & 24.27 & 0 & 0 & Cross-certification \\
\hline IFS & 46 & 26.59 & 46 & 26.59 & 0 & 0 & analysis: results for the \\
\hline EMAS III & 4 & 2.31 & 1 & 0.58 & 4 & 2.31 & whole sample \\
\hline
\end{tabular}


TQM

33,7

Thus, information discrepancy has emerged. This finding can be interpreted in two ways. First, companies do not upgrade their website information to obtain reputational benefits related to certifications without incurring costs. On the other hand, companies do not update the information not to incur the site's charges. In this light, this information discrepancy should be explained.

\section{2}

\section{Conclusions}

The present paper has provided a manifold contribution to the current literature. First, it examines the state of online CSR disclosure and QCD in the context of the Italian wine industry. Second, the study examines the effect of the size of Italian wineries on the level of CSR disclosure and QCD, as well as evaluating the role of geographic location as a moderating variable. Moreover, it explores how CSR disclosure impacts CFP and how CFP can impact CSR disclosure. Lastly, it investigates information consistency concerning voluntary standards, comparing the information provided by companies on their websites and data reported in the official databases of certification and accreditation bodies.

The study provides empirical evidence that wine companies exhibit a discrete level of online QCD. Furthermore, as the size of the winery increases, the level of CSR disclosure and $\mathrm{QCD}$ also rises. This finding is in line with the dominant literature on the subject. However, the Italian wine industry is mainly characterised by SMEs, for which costs related to nonfinancial information are sometimes not sustainable, as highlighted by Goedhuys and Sleuwaegen (2013).

According to institutional theory, firms operating in a common commitment context pay the same attention to CSR issues and disclosure practices (Martinez-Ferrero et al., 2016). Thus, even if Italian wine sector practices differ according to the grapes and production terroir of origin, our results show that the geographical location does not moderate the relationship between company size and the CSR disclosure level. This shared disclosure behaviour suggests that it is difficult to find different institutional approaches within the same country, even if regional regulations differ.

Additionally, the findings obtained in this research do not support the mainstream opinion, according to which companies involved in CSR achieve better financial performance. Accordingly, the relationship between CFP and CSR disclosure is negative. Symmetrically, CSR disclosure negatively affects the level of CFP.

\subsection{Implications}

The research findings, especially those concerning $\mathrm{QCD}$, confirmed the legitimacy theory assumption, suggesting that wine firms are responsible for stakeholders. In this perspective, considering the sensitiveness of wine stakeholders to CSR and quality issues, non-financial disclosure can be used as a strategic tool to obtain legitimacy. Thus, this study establishes the importance of CSRD and QCD, which lead organisations to employ energy, material, and human capital efficiently. Moreover, it offers useful insight into suitable communication strategies to obtain legitimacy from the relevant actors and stakeholders. Indeed, in a global market characterised by intense competition, online channels to disclose information allow firms to improve cross-national communication strategies.

Furthermore, engaging stakeholders through valuable interaction should facilitate the dissemination and implementation of sustainability and CSR practices. However, scholars have demonstrated that the wine sector is characterised by profound differences in the approach to quality and CSR due to the lack of information among the supply chain actors (Szolnoki, 2013; Fait et al., 2019). Therefore, the wine industry has to overcome the information flow barriers to become socially responsible. More specifically, in the relationship 
with clients and consumers, wine firms have to employ multiple communication channels including online communication channels that are strategic to convey CSR and quality information - to stay in contact with them. Among the available tools, the websites should be considered the main online space used by companies to disclose information officially (Lodhia et al., 2020). In this light, web-based tools allow wine organisations to overcome information asymmetries and easily engage with their stakeholders. The focal issue is sharing wine companies' vision and achieving CSR and quality objective, allowing the informative asymmetries to be reduced. From this perspective, CSR and quality strategies in the wine sector became a business driver that can influence the firms' image and products. This will, in turn, support wineries in accessing new markets and enhancing competitiveness.

Practitioners can use these findings to develop specific sustainability reporting/ communication strategies. Furthermore, this research may have implications also for regulators and policymakers, who can stimulate quality and CSR disclosure in the wine sector by allocating funds and promoting policies to increase non-financial information transparency for SMEs. Moreover, the paper has revealed that even if the literature on these issues is scant, online channels are considered useful to establish a sustained dialogue with stakeholders. Consequently, academics can replicate the study by adapting the same framework to other food and beverage industry sectors.

\subsection{Limitations and future research directions}

Finally, this paper's results should be interpreted in the context of the following limitations, which can represent a starting point for future research. First, this study examines only a limited number of companies. Second, the search process was performed during the lockdown. Therefore, the issues discussed may change in the near future due to the shift in priorities that the COVID-19 pandemic is causing. Third, it investigates only some of the certifications available in the food and beverage industry.

Future research could replicate this framework in other geographical contexts by comparing different countries in which different regulations exist. In addition, future research should be performed after the crisis generated by the COVID-19 global pandemic. Moreover, a comparison between the information provided on corporate websites and the information disclosed in non-financial reports would be interesting. Such a cross-analysis may be interesting for investigating how ESG factors strengthen QCD and CSR disclosure. Furthermore, future research should explore how sustainability can improve communication strategies (e.g. QCD, CSR disclosure, ESG disclosure) in terms of aiming to engage stakeholders and enhance company performance. Besides, a comparison of other CSR determinants would provide a more compelling overview of this research topic. Lastly, it would be interesting to explore how - using a different theoretical framework (e.g. stakeholder theory, stakeholder engagement) - our results can provide different insights for the wine sector.

\section{References}

Adams, C.A., Hill, W. and Roberts, C.B. (1998), "Corporate social reporting practices in Western Europe: legitimating corporate behaviour?”, British Accounting Review, Vol. 30, pp. 1-21.

Aggelogiannopoulos, D., Drosinos, E.H. and Athanasopoulos, P. (2007), "Implementation of a quality management system (QMS) according to the ISO 9000 family in a Greek small-sized winery: a case study", Food Control, Vol. 18 No. 9, pp. 1077-1085, ISSN 0956-7135, doi: 10.1016/j.foodcont. 2006.07.010.

Albitar, K., Hussainey, K., Kolade, N. and Gerged, A.M. (2020), "ESG disclosure and firm performance before and after IR", International Journal of Accounting and Information Management, Vol. 28 No. 3, pp. 429-444. 
TQM 33,7

\section{4}

Amran, A. (2012), "Exploring online sustainability disclosure among Malaysian company", Procedia Social and Behavioral Sciences, Vol. 65, pp. 761-767, ISSN 1877-0428, doi: 10.1016/j.sbspro.2012. 11.196.

Amran, A. and Haniffa, R. (2011), "Evidence in development of sustainability reporting: a case of a developing country", Business Strategy and the Environment, Vol. 20 No. 3, pp. 141-156.

Anderson, S.W., Daly, J.D. and Johnson, M.F. (1999), "Why firms seek ISO 9000 certifcation: regulatory compliance or competitive advantage?”, Production and Operations Management, Vol. 8, pp. $28-43$.

Arcese, G., Lucchetti, M.C. and Merli, R. (2013), "Social life cycle assessment as a management tool: methodology for application in tourism”, Sustainability, Vol. 5 No. 8, pp. 3275-3287, doi: 10.3390/ su5083275.

Arcese, G., Lucchetti, M.C. and Massa, I. (2017), "Modeling social life cycle assessment framework for the Italian wine sector", Journal of Cleaner Production, Vol. 140 No. 2, pp. 1027-1036, ISSN 09596526, doi: 10.1016/j.jclepro.2016.06.137.

Arora, M. and Lodhia, S. (2017), "The BP Gulf of Mexico oil spill: exploring the link between social and environmental disclosures and reputation risk management", Journal of Cleaner Production, Vol. 140 No. 3, pp. 1287-1297.

Atan, R.U.H.A.Y.A., Razali, F.A., Said, J.A.M.A.L.I.A.H. and Zainun, S.A.U.N.A.H. (2016), "Environmental, social and governance (ESG) disclosure and its effect on firm's performance: a comparative study", International Journal of Economics and Management, Vol. 10 Special, pp. 355-375.

Barber, N., Almanza, B.A. and Donovan, J.R. (2006), "Motivational factors of gender, income and age on selecting a bottle of wine", International Journal of Wine Marketing, Vol. 18 No. 3, pp. 218-232.

Baron, R.M. and Kenny, D.A. (1986), "The moderator-mediator variable distinction in social psychological research: conceptual, strategic, and statistical considerations", Journal of Personality and Social Psychology, Vol. 51 No. 6, pp. 1173-1182.

Berelson, B. (1952), Content Analysis in Communication Research, Free Press, Glencoe, IL.

Boselie, D., Henson, S. and Weatherspoon, D. (2003), "Supermarket procurement practices in developing countries: redefining the roles of the public and private sectors", American Journal of Agricultural Economics, Vol. 85 No. 5, pp. 1155-1161.

Boubaker, S., Lakhal, F. and Nekhili, M. (2011), "The determinants of web-based corporate reporting in France", Managerial Auditing Journal, Vol. 27 No. 2, doi: 10.1108/02686901211189835.

Boutin-Dufresne, F. and Savaria, P. (2004), "Corporate social responsibility and financial risk", The Journal of Investing, Vol. 13 No. 1, pp. 57-66.

Branco, M.C. and Rodrigues, L.L. (2006), "Corporate social responsibility and resource-based perspectives", Journal of Business Ethics, Vol. 69 No. 2, pp. 111-132.

Branco, M.C. and Rodrigues, L.L. (2008), "Factors influencing social responsibility disclosure by Portuguese companies", Journal of Business Ethics, Vol. 83 No. 4, pp. 685-701.

Brown, N. and Deegan, C. (1998), "The public disclosure of environmental performance informationa dual test of media agenda setting theory and legitimacy theory", Accounting and Business Research, Vol. 29 No. 1, pp. 21-41.

Campbell, J.L. (2004), Institutional Change and Globalisation, Princeton University Press, Princeton, NJ.

Carrol, A.B. and Shabana, K.M. (2010), "The business case for corporate social responsibility: a review of concepts, research and practice", International Journal of Management Reviews, Vol. 12 No. 1, $85 \mathrm{e} 105$.

Carroll, A.B. (1979), "A three-dimensional conceptual model of corporate performance”, Academy of Management Review, Vol. 4 No. 4, pp. 497-505.

Carvalho, F., Santos, G. and Gonçalves, J. (2018), "The disclosure of information on sustainable development on the corporate website of the certified Portuguese organisations", International Journal for Quality Research, Vol. 12, pp. 253-276. 10.18421/IJQR12.01-14. 
Chaudhri, V. and Wang, J. (2007), "Communicating corporate social responsibility on the internet: a case study of the top 100 information technology companies in India", Management Communication Quarterly, Vol. 21 No. 2, pp. 232-247, doi: 10.1177/0893318907308746.

Chauvey, J.N., Giordano-Spring, S., Cho, C.H. and Patten, D.M. (2015), "The normativity and legitimacy of CSR disclosure: evidence from France", Journal of Business Ethics, Vol. 130 No. 4, pp. 789-803.

Chen, S.H., Nasongkhla, J. and Donaldson, J.A. (2015), "University social responsibility (USR): identifying an ethical foundation within higher education institutions", Turkish Online Journal of Educational Technology-TOJET, Vol. 14 No. 4, pp. 165-172.

Chintrakarn, P., Jiraporn, P., Jiraporn, N. and Davidson, T. (2017), "Estimating the effect of corporate social responsibility on firm value using geographic identification", Asia Pacific Journal of Financial Studies, Vol. 46, pp. 276-304, doi: 10.1111/ajfs.12170.

Ciasullo, M.V. and Festa, G. (2014), "Ethical capital for the renaissance of disadvantaged territories the Libera Terra case study in the wine sector", Piccola Impresa/Small Business, ISSN 24215724, [S.1.] n. 3, available at: http://rivistapiccolaimpresa.uniurb.it/index.php/piccola/article/ view/180.

Cobelli, N. and Wilkinson, G. (2020), "Online wine purchasing: a comparison between South Africa and Italy", The TQM Journal, Vol. 32 Nos 4, pp. 837-847.

Cobelli, N., Chiarini, A. and Giaretta, E. (2021), "Enabling factors for adopting sustainable, organic wine production”, The TQM Journal, Vol. ahead-of-print No. ahead-of-print, pp. 1754-2731.

Cormier, D., Aerts, W., Ledoux, M.J. and Magnan, M. (2009), "Attributes of social and human capital disclosure and information asymmetry between managers and investors", Canadian Journal of Administrative Sciences, Vol. 26, pp. 71-88, doi: 10.1002/cjas.89.

Coy, D., Tower, G. and Dixon, K. (1993), "Quantifying the quality of tertiary education annual reports", Accounting and Finance, Vol. 33 No. 2, pp. 121-130.

Cuganesan, S., Guthrie, J. and Ward, L. (2010), "Examining CSR disclosure strategies within the Australian food and beverage industry", Accounting Forum, Elsevier, Vol. 34 Nos 3-4, pp. 169-183.

Debreceny, R., Gray, G.L. and Rahman, A. (2002), “The determinants of Internet financial reporting”, Journal of Accounting and Public Policy, Vol. 21 Nos 4-5, pp. 371-394.

Deegan, C. (2002), "The legitimising effect of social and environmental disclosures - a theoretical foundation", Accounting, Auditing and Accountability Journal, Vol. 15 No. 3, pp. 282-311, doi: 10. 1108/09513570210435852, 30.

Di Maggio, P.J. and Powell, W.W. (1991), "Introduction”, in Powell, W.W. and DiMaggio, P.J. (Eds), The New Institutionalism in Organizational Analysis, University of Chicago Press, Chicago, pp. 1-38.

Di Maggio, P.J. and Powell, W.W. (2012), "The iron cage revisited: institutional isomorphism and collective rationality in organisational fields [1983]", Contemporary Sociological Theory, p. 175, [S.1.] n. 3, available at: https://books.google.it/books?hl=it\&lr=\&id=I_x-pc2SJX0C\&oi= fnd\&pg =PA175\&dq=Di+Maggio,+P.J.+and +Powell, +W.W.+(2012),\&ots=_D7q1se$\mathrm{v} \&$ sig $=\mathrm{hDa} 4 \mathrm{mK} 8 \mathrm{QpT}$ TQHvKL7xC3dlSe00\&redir_esc $=\mathrm{y} \# \mathrm{v}=$ onepage $\& \mathrm{q}=\mathrm{Di} \% 20 \mathrm{Maggio} \% 2 \overline{\mathrm{C}}$ $\% 20$ P.J. $\% 20$ and $\% 20$ Powell $\% 2$ C $\% 20$ W.W. $\% 20(2012) \% 2$ C\&f=false.

Dos Santos, J.A., Moura-Leite, R., Pereira, M.W.G. and Pagán, M. (2020), "Social and environmental disclosure of the largest companies in Brazil's agribusiness sector", Social Responsibility Journal, Vol. ahead-of-print No. ahead-of-print, doi: 10.1108/SRJ-01-2019-0009.

Douglas, A., Doris, J. and Johnson, B. (2004), “Corporate social reporting in Irish financial institutions”, The TQM Magazine, Vol. 16 No. 6, pp. 387-395, doi: 10.1108/09544780410563301.

Dowling, J. and Pfeffer, J. (1975), "Organizational legitimacy: social values and organizational behavior", Pacific Sociological Review, Vol. 18 No. 1, pp. 122-136.

Du, S., Bhattacharya, C.B. and Sen, S. (2010), "Maximising business returns to corporate social responsibility (CSR): the role of the CSR communication", International Journal of Management Review, Vol. 12 No. 1, pp. 8-19. 
TQM 33,7

Dumay, J. and Cai, L. (2014), "A review and critique of content analysis as a methodology for inquiring into IC disclosure”, Journal of Intellectual Capital, Vol. 15 No. 2, pp. 264-290.

Eccles, R.G., Herz, R.H., Keegan, E.M. and Phillips, D.M. (2001), The Value Reporting Revolution: Moving beyond the Earnings Game, John Willey and Sons, New York, NY.

Elkington, J. (1998), Cannibals with Forks: The Triple Bottom Line of the 21st Century, New Society Publishers, Stoney Creek, CT.

European Commission (2001), "Green paper. Promoting a European framework for Corporate Social Responsibility”, Brussel, available at: https://www.europarl.europa.eu/meetdocs/committees/ deve/20020122/com(2001)366_en.pdf.

Fait, M., Vrontis, D., Maizza, A. and Cavallo, F. (2019), "Sustainability disclosure through virtual community: the case of the wine sector", British Food Journal, Vol. 122 No. 8, pp. 2513-2530, doi: 10.1108/BFJ-07-2019-0481.

Fatemi, A., Glaum, M. and Kaiser, S. (2018), "ESG performance and firm value: the moderating role of disclosure", Global Finance Journal, Vol. 38, pp. 45-64.

Flores, S.S.. (2018), "What is sustainability in the wine world? A cross-country analysis of wine sustainability frameworks", Journal of Cleaner Production, Vol. 172, pp. 2301-2312, ISSN 09596526, doi: 10.1016/j.jclepro.2017.11.181.

Friedman, M. (2007), "The social responsibility of business is to increase its profits", in Zimmerli, W.C., Holzinger, M. and Richter, K. (Eds), Corporate Ethics and Corporate Governance, Springer Berlin/Heidelberg.

Gamerschlag, R., Möller, K. and Verbeeten, F. (2011), "Determinants of voluntary CSR disclosure: empirical evidence from Germany", Review of Managerial Science, Vol. 5 Nos 2-3, pp. 233-262.

Garde Sanchez, R., Rodríguez Bolívar, M.P. and López Hernandez, A.M. (2021), "Which are the main factors influencing corporate social responsibility information disclosures on universities' websites", International Journal of Environmental Research and Public Health, Vol. 18 No. 2, p. 524 .

Garde-Sánchez, R., Manuel Pedro Rodríguez, B., Antonio, M. and López-Hernández (2013), "Online disclosure of university social responsibility: a comparative study of public and private US universities", Environmental Education Research, Vol. 19 No. 6, pp. 709-746, doi: 10.1080/ 13504622.2012.749976.

Georgiadou, E. and Nickerson, C. (2020), 'Exploring strategic CSR communication on UAE banks' corporate websites", Corporate Communications: An International Journal, Vol. 25 No. 3, pp. 413-428, doi: 10.1108/CCIJ-02-2020-0044.

Giacomini, D., Zola, P., Paredi, D. and Mazzoleni, M. (2020), "Environmental disclosure and stakeholder engagement via social media: state of the art and potential in public utilities", Corporate Social Responsibility and Environmental Management, Vol. 27, pp. 1552-1564, doi: 10. 1002/csr.1904.

Giannarakis, G. (2014), “The determinants influencing the extent of CSR disclosure”, International Journal of Law and Management, Vol. 56 No. 5, pp. 393-416, doi: 10.1108/IJLMA-05-2013-0021.

Goedhuys, M. and Sleuwaegen, L. (2013), "The impact of international standards certification on the performance of firms in less developed countries", World Development, Vol. 47, pp. 87-101, ISSN 0305-750X, doi: 10.1016/j.worlddev.2013.02.014.

Gómez-Conde, J., López-Valeiras, E., González-Sánchez, M.B. and Rodríguez-González, E. (2012), "Sistemas contables de gestión, recursos comerciales y capital humano. Un análisis en el sector agroalimentario español”, Agrociencia, Vol. 46 No. 1, pp. 87-99, available at: http://www.scielo. org.mx/scielo.php?script $=$ sci_arttext\&pid $=$ S140531952012000100008\&lng $=$ es\&tlng $=\mathrm{es}$ (accessed 10 noviembre 2020).

Gray, S.J., Meek, G.K. and Roberts, C.B. (1995), "Factors influencing voluntary annual report disclosures by US, UK and continental European multinational corporations", Journal of International Business Studies, Vol. 26, No. 3, pp. 555-572. 
Gray, R. and Milne, M.J. (2015), "It's not what you do, it's the way that you do it? Of method and madness", Critical Perspectives on Accounting, Vol. 32, pp. 51-66.

Gray, R., Owen, D. and Adams, C. (1996), Accounting and Accountability: Changes and Challenges in Corporate Social and Environmental Reporting, Prentice Hall, New York.

Gray, R., Javad, M., Power, D.M. and Sinclair, C.D. (2001), "Social and environmental disclosure and corporate characteristics: a research note and extension", Journal of Business Finance and Accounting, Vol. 28 Nos 3-4, pp. 327-356.

Grecco, M.C.P., Milani Filho, M.A.F., Segura, L.C., Sanchez, I.M.G. and Dominguez, L.R. (2013), "The voluntary disclosure of sustainable information: a comparative analysis of Spanish and brazilian companies", Revista de Contabilidade e Organizações, Vol. 7 No. 17, pp. 45-55.

Hackston, D. and Milne, M.J. (1996), "Some determinants of social and environmental disclosures in New Zealand companies", Accounting, Auditing and Accountability Journal, Vol. 9 No. 1, pp. 77-108, doi: 10.1108/09513579610109987.

Haji, A.A. and Anifowose, M. (2017), "Initial trends in corporate disclosures following the introduction of integrated reporting practice in South Africa”, Journal of Intellectual Capital, Vol. 18 No. 2, pp. 373-393, doi: 10.1108/JIC-01-2016-0020.

Handschuch, C., Wollni, M. and Villalobos, P. (2013), "Adoption of food safety and quality standards among chilean raspberry producers - do smallholders benefit?", Food Policy, Vol. 40, pp. 64-73, ISSN 0306-9192, doi: 10.1016/j.foodpol.2013.02.002.

Haniffa, R.M. and Cooke, T.E., (2005), "The impact of culture and governance on corporate social reporting", Journal of Accounting and Public Policy, Vol. 24 No. 5, pp. 391-430, ISSN 0278-4254, doi: 10.1016/j.jaccpubpol.2005.06.001.

He, M., Wu, Z., Li, W. and Zeng, Y. (2015), "Forest certification in collectively owned forest areas and sustainable forest management: a case of cooperative-based forest certification in China", Smallscale Forestry, Vol. 14 No. 2, pp. 245-254, doi: 10.1007/s11842-015-9285-y.

Henson, S. and Reardon, T. (2005), "Private agri-food standards: implications for food policy and the agri-food system”, Food Policy, Vol. 30 No. 3, pp. 241-253, ISSN 0306-9192, doi: 10.1016/j.foodpol. 2005.05.002.

Hollebeek, L.D., Jaeger, S.R., Brodie, R.J. and Balemi, A. (2007), "The influence of involvement on purchase intention for new world wine", Food Quality and Preference, Vol. 18 No. 8, pp. 1033-1049.

Hsieh, Y. (2012), "Hotel companies' environmental policies and practices: a content analysis of their web pages", International Journal of Contemporary Hospitality Management, Vol. 24 No. 1, pp. 97-121, doi: 10.1108/095961112.

Iaia, L., Vrontis, D., Maizza, A., Fait, M., Scorrano, P. and Cavallo, F. (2019), "Family businesses, corporate social responsibility, and websites: the strategies of Italian wine firms in talking to stakeholders", British Food Journal, Vol. 121 No. 7, pp. 1442-1446, doi: 10.1108/BFJ-072018-0445.

Iazzi, A., Pizzi, S., Iaia, L. and Turco, M. (2020), “Communicating the stakeholder engagement process: a cross-country analysis in the tourism sector", Corporate Social Responsibility and Environmental Management, Vol. 27 No. 4, pp. 1642-1652.

Inoue, Y. and Lee, S. (2011), "Effects of different dimensions of corporate social responsibility on corporate financial performance in tourism-related industries", Tourism Management, Vol. 32 No. 4, pp. 790-804.

Kang, J. and Hustvedt, G. (2014), "Building trust between consumers and corporations: the role of consumer perceptions of transparency and social responsibility", Journal of Business Ethics, Vol. 125 No. 2, pp. 253-265.

Kansal, M., Joshi, M. and Batra, G.S. (2014), "Determinants of corporate social responsibility disclosures: evidence from India”, Advances in Accounting, Vol. 30 No. 1, pp. 217-229. 
TQM 33,7

\section{8}

Karipidis, P., Athanassiadis, K., Aggelopoulos, S. and Giompliakis, E. (2009), "Factors affecting the adoption of quality assurance systems in small food enterprises", Food Control, Vol. 20 No. 2, pp. 93-98, ISSN 0956-7135, doi: 10.1016/j.foodcont.2008.02.008.

Khan, H.U.Z. (2010), "The effect of corporate governance elements on corporate social responsibility (CSR) reporting: empirical evidence from private commercial banks of Bangladesh", International Journal of Law and Management, Vol. 52 No. 2, pp. 82-109.

Kiliç, M. (2016), "Online corporate social responsibility (CSR) disclosure in the banking industry: evidence from Turkey", International Journal of Bank Marketing, Vol. 34 No. 4, pp. 550-569, doi: 10.1108/IJBM-04-2015-0060.

Kim, J.S., Song, H.J. and Lee, C.K. (2016), "Effects of corporate social responsibility and internal marketing on organizational commitment and turnover intentions", International Journal of Hospitality Management, Vol. 55, pp. 25-32.

Kolk, A. (2004), "A decade of sustainability reporting: developments and significance", International Journal of Environment and Sustainable Development, Vol. 3 No. 1, doi: 10.1504/IJESD.2004.004688.

Kostova, T. and Roth, K. (2002), "Adoption of an organizational practice by subsidiaries of multinational corporations: institutional and relational effects", Academy of Management Journal, Vol. 45 No. 1, pp. 215-233.

Kotler, P. and Lee, N. (2005), Corporate Social Responsibility: Doing the Most Good for Your Company and Your Cause, John Wiley, Hoboken, New Jersey, NJ.

Krippendorff, K. (1980), "Validity in content analysis", in Mochmann, E. (Ed.), Computerstrategien $f \tilde{A} 1 / 4$ r die kommunikationsanalyse, Campus, Frankfurt, pp. 69-112, available at: http://repository. upenn.edu/asc_papers/291.

Lawal, E., May, G. and Stahl, B. (2017), "The significance of corporate social disclosure for high-tech manufacturing companies: focus on employee and community aspects of sustainable development", Corporate Social Responsibility and Environmental Management, Vol. 24 No. 4, pp. 295-311.

Lindgreen, A., Swaen, V. and Johnston, W.J. (2009), "Corporate social responsibility: an empirical investigation of U.S. organisations", Journal of Business Ethics, Vol. 85 Suppl. 2, pp. 303-323.

Line, M., Hawley, H. and Krut, R. (2002), "Development in global environmental and social reporting”, Corporate Environmental Strategy, Vol. 9 No. 1, pp. 69-78, doi: 10.1016/S1066-7938(01)00159-2.

Lodhia, S. (2018), "Is the medium the message? Advancing the research agenda on the role of communication media in sustainability reporting", Meditari Accountancy Research, Vol. 26 No. 1, pp. 2-12.

Lodhia, S., Kaur, A. and Stone, G. (2020), "The use of social media as a legitimation tool for sustainability reporting”, Meditari Accountancy Research, Vol. 28 No. 4, doi: 10.1108/MEDAR09-2019-0566.

Manes Rossi, F., Nicolò, G. and Tartaglia Polcini, P. (2018), "New trends in intellectual capital reporting: exploring online intellectual capital disclosure in Italian universities", Journal of Intellectual Capital, Vol. 19, pp. 814-835, doi: 10.1108/JIC-09-2017-0119.

Margolis, J.D. and Walsh, J.P. (2001), in:People and Profits? the Search for A Link between A Company's Social and Financial Performance, Lawrence Elbaum, Mahwah, New Jersey, NJ.

Martínez-Ferrero, J. Ruiz-Cano, D. and García-Sánchez, I. (2016), "The causal link between sustainable disclosure and information asymmetry: the moderating role of the stakeholder protection context", Corporate Social Responsibility and Environmental Management, Vol. 23, pp. 319-332, doi: 10.1002/csr.1379.

Mathews, M.R. (1995), "Social and environmental accounting: a practical demonstration of ethical concern?”, Journal of Business Ethics, Vol. 14 No. 8, pp. 663-671.

McMillan, S.J. (2000), "The microscope and the moving target: the challenge of applying content analysis to the World Wide Web", Journalism and Mass Communication Quarterly, Vol. 77 No. 1, pp. 80-98. 
McWilliams, A. and Siegel, D. (2000), "Corporate social responsibility and financial performance: correlation or misspecification?", Journal of Strategic Management, Vol. 21, pp. 603-609.

Merkl-Davies, D.M. and Brennan, N. (2007), "Discretionary disclosure strategies in corporate narratives: incremental information or impression management?", Journal of Accounting Literature, Vol. 26, pp. 116-196.

Corporate Social Responsibility in wineries

Merli, R., Preziosi, M. and Massa, I. (2015), "Social values and sustainability: a survey on drivers, barriers and benefits of SA8000 certification in Italian firms", Sustainability, Vol. 7 No. 4, pp. 4120-4130, doi: 10.3390/su7044120.

Mio, C., Venturelli, A. and Leopizzi, R. (2015), "Management by objectives and corporate social responsibility disclosure", Accounting, Auditing and Accountability Journal, Vol. 28 No. 3, pp. 325-364, doi: 10.1108/AAAJ-09-2013-1480.

Muñoz, R.M., Fernández, M.V. and Salinero, Y. (2021), "Sustainability, corporate social responsibility, and performance in the Spanish wine sector", Sustainability, Vol. 13 No. 1, p. 7.

Neu, D., Warsame, H. and Pedwell, K. (1998), "Managing public impressions: environmental disclosures in annual reports", Accounting, Organizations and Society, Vol. 23 No. 3, pp. 265-282.

Nicolò, G., Zanellato, G. and Tiron-Tudor, A. (2020a), "Integrated reporting and European state-owned enterprises: a disclosure analysis pre and post 2014/95/EU", Sustainability, Vol. 12 No. 5, p. 1908, doi: 10.3390/su12051908.

Nicolò, G., Aversano, N., Sannino, G. and Tartaglia Polcini, P. (2020b), "ICD corporate communication and its determinants: evidence from Italian listed companies' websites", Meditari Accountancy Research, Vol. ahead-of-print No. ahead-of-print, doi: 10.1108/MEDAR-03-2020-0834.

Normilia, A.W., Nurul Nadia Abd, A. and Halim, R.A. (2017), "Networking and innovation performance of micro-enterprises in Malaysia: the moderating effects of geographical location", Journal of Social Sciences and Humanities, Vol. 25 No. S, pp. 281-292, ISSN: 0128-7702.

Notarnicola, B., Tassielli, G. and Nicoletti, G.M. (2003), "LCA of wine production”, EnvironmentallyFriendly Food Production, Wood-head-Publishing and CRC Press, Cambridge, pp. 306-326.

OIV (2008), "Resolution CST 1/2008. OIV Guidelines for sustainable vitiviniculture: production, processing and packaging of products", available at: www.oiv.int/public/medias/395/viti-20111-en.pdf (accessed 11 February 2019).

Ortas, E., Álvarez, I., Jaussaud, J. and Garayar, A. (2015), "The impact of institutional and social context on corporate environmental, social and governance performance of companies committed to voluntary corporate social responsibility initiatives", Journal of Cleaner Production, Vol. 108, pp. 673-684, ISSN 0959-6526, doi: 10.1016/j.jclepro.2015.06.089.

Othman, S., Darus, F. and Arshad, R. (2011), "The influence of coercive isomorphism on corporate social responsibility reporting and reputation", Social Responsibility Journal, Vol. 7 No. 1, pp. 119-135, doi: 10.1108/17471111111114585.

Palazzo, M., Vollero, A. and Siano, A. (2020), "From strategic corporate social responsibility to value creation: an analysis of corporate website communication in the banking sector", International Journal of Bank Marketing.

Patten, D.M. (1991), "Exposure, legitimacy, and social disclosure", Journal of Accounting and Public Policy, Vol. 10 No. 4, pp. 297-308.

Patten, D.M., Ren, Y. and Zhao, N. (2015), "Standalone corporate social responsibility reporting in China: an exploratory analysis of its relation to legitimation", Social and Environmental Accountability Journal, Vol. 35 No. 1, pp. 17-31.

Pedersen, E.R.G., Neergaard, P., Pedersen, J.T. and Gwozdz, W. (2013), "Conformance and deviance: company responses to institutional pressures for corporate social responsibility reporting", Business Strategy and the Environment, Vol. 22 No. 6, pp. 357-373.

Pinkston, T.S. and Carroll, A.B. (1996), "A retrospective examination of CSR orientations: have they changed?”, Journal of Business Ethics, Vol. 15, pp. 199-206. 
TQM 33,7

Porter, M.E. and Kramer, M.R. (2007), "Strategia e società. Il punto d'incontro tra il vantaggio competitivo e la Corporate Social Responsibility", Harvard Business Review Italia, Vol. 14 Nos 1/2, pp. 1-18.

Pradhan, S. (2018), "Role of CSR in the consumer decision making process-The case of India", Social Responsibility Journal, Vol. 14 No. 1, doi: 10.1108/SRJ-06-2016-0109.

Preston, L.E. and O’bannon, D.P. (1997), "The corporate social-financial performance relationship: a typology and analysis", Business and Society, Vol. 36 No. 4, pp. 419-429.

Rahman, N.H.W., Zain, M.M. and Al-Haj, N.H.Y.Y. (2011), "CSR disclosures and its determinants: evidence from Malaysian government link companies", Social Responsibility Journal, Vol. 7 No. 2, pp. 181-201, doi: 10.1108/17471111111141486.

Reverte, C. (2009), "Determinants of corporate social responsibility disclosure ratings by Spanish listed firms", Journal of Business Ethics, Vol. 88 No. 2, pp. 351-366.

Roberts, R.W. (1992), "Determinants of corporate social responsibility disclosure: an application of stakeholder theory", Accounting, Organisations and Society, Vol. 17 No. 6, pp. 595-612.

Rodríguez Bolívar, M.P., Garde Sánchez, R. and López Hernández, A.M. (2013), "Online disclosure of corporate social responsibility information in leading anglo-American universities", Journal of Environmental Policy and Planning, Vol. 15 No. 4, pp. 551-575, doi: 10.1080/1523908X.2013. 817945.

Russo-Spena, T., Tregua, M. and De Chiara, A. (2018), "Trends and drivers in CSR disclosure: a focus on reporting practices in the automotive industry", Journal of Business Ethics, Vol. 151 No. 2, pp. 563-578.

Said, R., Zainuddin, Y.H. and Haron, H. (2009), "The relationship between corporate social responsibility disclosure and corporate governance characteristics in Malaysian public listed companies”, Social Responsibility Journal, Vol. 5 No. 2, pp. 212-226.

Salehi, M., DashtBayaz, M.L. and Khorashadizadeh, S. (2018), "Corporate social responsibility and future financial performance”, EuroMed Journal of Business, Vol. 13 No. 3, pp. 351-371, doi: 10. 1108/EMJB-11-2017-0044.

Scholtens, B. (2008), "A note on the interaction between corporate social responsibility and financial performance", Ecological Economics, Vol. 68 Nos 1-2, pp. 46-55.

Siregar, S.V. and Bachtiar, Y. (2010), "Corporate social reporting: empirical evidence from Indonesia stock exchange", International Journal of Islamic and Middle Eastern Finance and Management, Vol. 3 No. 3, pp. 241-252.

Siva, V., Gremyr, I., Bergquist, B., Garvare, R., Zobel, T. and Isaksson, R. (2016), "The support of Quality Management to sustainable development: a literature review", Journal of Cleaner Production, Vol. 138 No. 2, pp. 148-157, ISSN 0959-6526, doi: 10.1016/j.jclepro.2016.01.020.

Sobhani, F.A., Amran, A. and Zainuddin, Y. (2012), "Sustainability disclosure in annual reports and websites: a study of the banking industry in Bangladesh", Journal of Cleaner Production, Vol. 23 No. 1, pp. 75-85, ISSN 0959-6526, doi: 10.1016/j.jclepro.2011.09.023.

Spence, M., Gherib, J.B.B. and Biwole, V.O. (2011), "Sustainable entrepreneurship: is entrepreneurial will enough? A north-south comparison”, Journal of Business Ethics, Vol. 99, pp. 335-367, doi: 10.1007/s10551-010-0656-1.

Starke, F., Eunni, R.V., Manoel Martins Dias Fouto, N. and Felisoni de Angelo, C. (2012), "Impact of ISO 9000 certification on firm performance: evidence from Brazil", Management Research Review, Vol. 35 No. 10, pp. 974-997, doi: 10.1108/01409171211272697.

Striukova, L., Unerman, J. and Guthrie, J. (2008), “Corporate reporting of intellectual capital: evidence from UK companies”, The British Accounting Review, Vol. 40 No. 4, pp. 297-313, ISSN 0890-8389, doi: 10.1016/j.bar.2008.06.001.

Suárez-Rico, Y.M., García-Benau, M.A. and Gómez-Villegas, M. (2019), "CSR communication through Facebook in the Latin American integrated market (MILA): disclosure, interactivity and 
legitimacy”, Meditari Accountancy Research, Vol. 27 No. 5, pp. 741-760, doi: 10.1108/MEDAR-032018-0313.

Suchman, M.C. (1995), "Managing legitimacy: strategic and institutional approaches", Academy of Management Review, Vol. 20 No. 3, doi: 10.5465/amr.1995.9508080331.

Swinbank, A. (2009), EU Support for Biofuels and Bioenergy, Environmental Sustainability Criteria, and Trade Policy, International Centre for Trade and Sustainable Development, No. 17, Geneva.

Szolnoki, G. (2013), "A cross-national comparison of sustainability in the wine industry”, Journal of Cleaner Production, Vol. 53, pp. 243-251.

Tibiletti, V., Marchini, P.L., Furlotti, K. and Medioli, A. (2020), "Does corporate governance matter in corporate social responsibility disclosure? Evidence from Italy in the "era of sustainability", Corporate Social Responsibility and Environmental Management, Vol. 28, pp. 896-907.

Ullah, B., Wei, Z. and Xie, F. (2014), "ISO certification, financial constraints, and firm performance in Latin American and Caribbean countries”, Global Finance Journal, Vol. 25 No. 3, pp. 203-228, ISSN 1044-0283, doi: 10.1016/j.gfj.2014.10.003.

Ullmann, A. (1985), "Data in search of a theory: a critical examination of the relationships among social performance, social disclosure, and economic performance of U. S. Firms", The Academy of Management Review, Vol. 10 No. 3, pp. 540-557.

Wachira, M.M., Berndt, T. and Romero, C.M. (2019), "The adoption of international sustainability and integrated reporting guidelines within a mandatory reporting framework: lessons from South Africa", Social Responsibility Journal, Vol. 16 No. 5, pp. 613-629, doi: 10.1108/SRJ-12-2018-0322.

Xiao, J.Z., Yang, H. and Chow, C.W. (2004), "The determinants and characteristics of voluntary Internet-based disclosures by listed Chinese companies", Journal of Accounting and Public Policy, Vol. 23 No. 3, pp. 191-225.

Yen, Y.S. (2014), “A comparison of quality satisfaction between transactional and relational customers in e-commerce", The TQM Journal, Vol. 26 No. 6, pp. 577-593.

Yu, H.C., Kuo, L. and Kao, M.F. (2017), "The relationship between CSR disclosure and competitive advantage", Sustainability Accounting, Management and Policy Journal, Vol. 8 No. 5, pp. 547-570, doi: 10.1108/SAMPJ-11-2016-0086.

Zamir, F. and Saeed, A. (2020), "Location matters: impact of geographical proximity to financial centers on corporate social responsibility (CSR) disclosure in emerging economies", Asia Pacific Journal of Management, Vol. 37, pp. 263-295, doi: 10.1007/s10490-018-9619-3.

\section{Further reading}

Bondy, K., Matten, D. and Moon, J. (2008), "Multinational corporation codes of conduct: governance tools for corporate social responsibility?", Corporate Governance: An International Review, Vol. 16, pp. 294-311, doi: 10.1111/j.1467-8683.2008.00694.x.

Chaney, I.M. (2000), "External search effort for wine", International Journal of Wine Marketing, Vol. 12 No. 2, p. 521 .

García-Sánchez, I.M., Gomez-Miranda, M.E., David, F. and Rodríguez-Ariza, L. (2019), "The explanatory effect of CSR committee and assurance services on the adoption of the IFC performance standards, as a means of enhancing corporate transparency", Sustainability Accounting, Management and Policy Journal, Vol. 10 No. 5, pp. 773-797, doi: 10.1108/SAMPJ-092018-0261.

Milne, M.J. and Patten, D.M. (2002), "Securing organisational legitimacy: an experimental decision case examining the impact of environmental disclosures", Accounting, Auditing and Accountability Journal, Vol. 15 No. 3, pp. 372-405.

Pisani, N., Kourula, A., Kolk, A. and Meijer, R. (2017), "How global is international CSR research? Insights and recommendations from a systematic review", Journal of World Business, Vol. 52 No. 5, pp. 591-614.
Corporate Social

Responsibility in wineries 
Son-Turan, S. and Lambrechts, W. (2019), "Sustainability disclosure in higher education", International Journal of Sustainability in Higher Education, Vol. 20 No. 7, pp. 1143-1170, doi: 10.1108/IJSHE-02-2019-0070.

\section{About the authors}

Benedetta Esposito is a PhD Student in Big Data Management in the Department of Management and Innovation Systems at the University of Salerno. Her research is mainly focused on Corporate Social Responsibility, Sustainability and Circular Economy in the agri-food sector. Benedetta Esposito is the corresponding author and can be contacted at: besposito@unisa.it

Maria Rosaria Sessa is a $\mathrm{PhD}$ in Management and Information Technology and Research Fellow in Commodity Science in the Department of Management and Innovation Systems at the University of Salerno, where she teaches Quality Management and Control of Tourist Service. Her research mainly focuses on developing quality and environmental management systems, Corporate Social Responsibility, environmental assessment tools, and competence certification.

Daniela Sica is a $\mathrm{PhD}$ in Commodity Science and lecturer in Quality Management and Control of Tourist Service in the Department of Management and Innovation Systems at the University of Salerno. Her research interests mainly focus on the sustainable production process, Quality Management Systems and Corporate Social Responsibility.

Ornella Malandrino is a Full Professor of Commodity Science at Salerno University, where she teaches and conducts research on quality, sustainability and Corporate Social Responsibility. She is the Inter-departmental Observatory director for Gender Studies and Equal Opportunities at the University of Salerno.

For instructions on how to order reprints of this article, please visit our website: 